\title{
Facial Displays in Red-Capped Mangabeys (Cercocebus torquatus): Repertoire, Social Context and Potential Intentionality
}

\author{
Juliette Aychet ${ }^{1}$, Catherine Blois-Heulin ${ }^{1}$, Elisabetta Palagi ${ }^{2}$, Alban Lemasson ${ }^{1,3}$ \\ ${ }^{1}$ Univ Rennes, Normandie Univ, CNRS, EthoS (Éthologie animale et humaine) - UMR 6552, \\ F-35380 Paimpont, France \\ ${ }^{2}$ University of Pisa, Unit of Ethology, Department of Biology, Pisa, Italy \\ ${ }^{3}$ Institut Universitaire de France
}

\begin{abstract}
Author Note
Juliette Aychet: ORCID https://orcid.org/0000-0002-2415-1028

Catherine Blois-Heulin: ORCID https://orcid.org/0000-0002-5890-8391

Elisabetta Palagi: ORCID https://orcid.org/0000-0002-2038-4596

Alban Lemasson: ORCID https://orcid.org/0000-0001-8418-5601
\end{abstract}

Correspondence concerning this article should be addressed to Juliette Aychet, UMR 6552, Université de Rennes 1, Station Biologique de Paimpont, 35380 Paimpont, France. Email : juliette.aychet@gmail.com

The authors declare that they have no conflict of interest.

We thank Arnaud Rossard and Philippe Bec for taking care of the monkeys and for their flexibility regarding our observation schedule. Thanks to Loïc Pougnault and Pablo Pezzino for the second observation of our videos. We also thank Véronique Guyot for her helpful advice on statistical analyses, and are grateful to Ann Cloarec for correcting the English writing.

\section{Citation}

Aychet, J., Blois-Heulin, C., Palagi, E., \& Lemasson, A. (2021). Facial displays in redcapped mangabeys (Cercocebus torquatus): Repertoire, social context, and potential intentionality. Journal of Comparative Psychology, 135(1), 98-113.

https://doi.org/10.1037/com0000252 


\begin{abstract}
Primate communication relies strongly on the visual modality, notably through the production of a wide range of expressive facial signals. We investigated here the facial display repertoire of a relatively little-studied cercopithecid species, red-capped mangabeys (Cercocebus torquatus), and questioned whether their facial displays were dependent on social contexts and accompanied by indices of intentionality. Although the dual intentional and emotional use of apes' facial expressions has recently been suggested, the question of whether monkeys produce facial expressions intentionally to communicate remains open. We described six facial displays produced by captive red-capped mangabeys in social contexts. They are based on movements of the mouth, eyebrows and ears, possibly graded in intensity and produced independently or in combination. We showed that most of the facial displays were produced preferentially in specific social contexts, and that repertoires varied with subjects' characteristics, highlighting the communicative function of these displays. Moreover, behavioral markers of intentionality commonly used in gestural studies were found to accompany the production of some of the facial signals observed. Particularly, playful "open mouth" appeared strongly associated with intentionality indices, as previously noticed in ape species. All other facial displays, except yawns, did not exhibit all defined intentional indices but were, at least, directed towards a recipient. Interestingly, yawns presented different variants of intensity associated presumably with different social functions. Altogether, these results emphasize the communicative function of red-capped mangabeys' facial displays, and provide a basis for further research on their intentional communication.
\end{abstract}

Keywords: Monkeys, Intentionality, Facial expression, Play face, Yawn 


\section{Introduction}

Primate communication strongly relies on the visual modality (Redican 1975; Liebal et al., 2014a) through a variety of gestural and postural signals. Moreover, compared to other mammals, primates produce a wide range of expressive facial movements, due to their complex facial musculature (Burrows 2008; Diogo et al., 2009). Facial expressions can involve movements of the mouth and lips, eyelids and eyebrows, forehead and ears (van Hooff 1967; Waller and Micheletta 2013). Substantial variations are notable between primate genera and species regarding facial mobility (Santana et al,. 2014) and facial expression repertoires (Marler 1965; van Hooff 1967). Thus, the understanding of visual communication in primate species needs precise descriptions of their facial expression repertoire and the context of production as their communicative signals. Some authors include facial displays in the gestural domain (e.g. Altmann 1962; Call and Tomasello 2007; Chalmers 1968a; Dube 2013; Hesler and Fischer 2007; Hinde and Rowell 1962; Hostetter et al., 2001; Maestripieri 1997, 2005; Poss et al., 2006; Wolfheim and Rowell 1972); whereas others consider facial displays as disentangled from gestures due to differences in the definitions of signal intentionality (e.g. Byrne et al., 2017; Graham et al., 2017; Genty et al., 2009; Hobaiter and Byrne 2011; Liebal et al., 2004b, 2006; Pollick and de Waal 2007; Roberts et al., 2014). Indeed, the intentional use of facial expressions in primates is still matter of debate (Arbib et al., 2008; Hopkins et al., 2011; Slocombe et al., 2011).

Non-human primates seem to have a voluntary control of their facial movements, which is required for the flexible use of facial expressions. Regarding neuroanatomical data from humans and great apes, facial expressions are controlled by both voluntary and emotional pathways acting in parallel within the facial motor system that differs from the motor system controlling limb movements (Cattaneo and Pavesi 2014; Müri 2016; Sliwa et al., 2018; Sherwood et al., 2004, 2005;). Moreover, some facial expression asymmetries are associated with attention-getting calls in chimpanzees, suggesting voluntary control of these facial movements (Hopkins et al., 2011; Reynolds-Losin et al., 2008). This possible voluntary control may reveal that primates could use facial expressions intentionally as communication signals.

The distinction between intentional behaviors and intentional communication was previously addressed by Bretherton and Bates (1979) in their developmental studies in children, based on the implication of social agents within intentional sequences of behavior. Then, the philosophical stance of intentional communication as a goal-directed process was formulated by Dennett (1983), who defined different degrees of intentionality. The first degree, as studied in animal communication, supposes that an intentional signal would be controlled and produced voluntarily by a signaler and directed towards a recipient in order to trigger the appropriate response by the receiver (Hobaiter and Byrne 2013; Roeder and Gosset 2001). The goaldirectedness discriminates intentional communicative signals from mere informative signals, which convey messages without being voluntarily emitted by the signaler (Poggi and D'Errico 2012). One example of "informative signal" could be piloerection, which conveys information about the individual's internal state (e.g. Benedek and Kaernbach 2011; Dettling et al., 1998) without appearing voluntarily emitted. Bard (1992) introduced Bates' definition of intentional communication to the study of primate communication, distinguishing intentional 
communication from other intentional behaviors in orangutan mother-infant interactions. In the same line, several behavioral indices of intentional communication inherited from child developmental studies were then applied to non-human gestural studies to assess intentionality (see for reviews: Byrne et al., 2017; Leavens et al., 2005, Liebal et al., 2014c; Schel et al., under review; Townsend et al., 2017). Townsend et al. (2017) recently gathered these indices in a general framework implying three main criteria to attribute intentionality to communicative signals: the signal has to be directed towards a recipient, produced in order to reach a particular social goal, and has to be followed by a response from the recipient that is consistent with the goal that is deduced for the signaler. This last criterion, related to the communicative value of the signal (Altmann 1968; Green 1975; Marler 1967), would imply that the signal is followed by a consistent change in the recipient's behavior, consistency with signaler's intention corresponding to an acceptance or a refusal of signaler's goal. Following this framework, appropriate behavioral markers have thus to accompany the production of the signal so that it could be associated with intentionality. These behavioral markers may have validity limitations to admit a signal's intentionality, since each of them can also be explained by unintentional processes, such as learning or changes in signaler's emotional state (Graham et al., 2019; Liebal et al., 2014b). It has been argued that the more indices observed, the more we get confidence that the criteria are fulfilled and so that the signal might be intentional (Schel et al., 2013), considering that several convergent indices are more likely to be explained by a single cognitive mechanism (intentionality) rather than a series of lower-level cognition explanations (Byrne and Bates 2006; Liebal et al., 2014b; Townsend et al., 2017). However, these markers have to be used cautiously when studying animal signals, with due consideration to all possible cognitive mechanisms underlying signal production.

A signal is considered as recipient-directed if it is produced in the presence of potential receivers (i.e. "socially used"), and physically directed to another individual (Call and Tomasello 2007; Leavens et al., 1996, 2004a; Leavens and Hopkins 1998; Liebal et al., 2004c, 2014b; Schel et al., under review; Tomasello et al., 1985, 1994). To discriminate sociallydependent signals from others, supplementary indicators should be taken into account, such as the fact that the signaler first checked the audience's attentional state before producing the display (Genty et al., 2009; Graham et al., 2017; Hobaiter and Byrne 2011a; Schel et al., under review), at least in case of signals that have to be perceived on the visual channel. Furthermore, the sensitivity to the attentional state of the recipient, both regarding the rate or the modality of the signal, is often studied as an indicator of intentional use of gestures (e.g. Bourjade et al., 2013; Demuru et al., 2015; Leavens et al., 2004b; Liebal et al., 2004c; Maille et al., 2012; Meunier et al., 2013; Poss et al., 2006). The second dimension of intentional communication, i.e. the goal-directedness of the signal, could be checked by monitoring response-waiting from the signaler after it produced the display (Call and Tomasello 2007; Cartmill and Byrne 2010; Graham et al., 2017; Hobaiter and Byrne 2011a; Liebal et al., 2004c; Molesti et al., 2019; Pika et al., 2003; Roberts et al., 2012, 2014; Schel et al., under review; Tomasello et al., 1985, 1994). Moreover, goal-directedness is recognized when the signaler stops producing the signal once the presumed goal has been reached, and repeats and/or elaborates the signals in case the goal has not been met yet (Cartmill and Byrne 2007, 2010; Genty et al., 2014; Graham et al., 2017; 
Gupta and Sinha 2019; Hobaiter and Byrne 2011b; Hostetter et al., 2001; Leavens et al., 2005; Liebal et al., 2004b, 2014b; Roberts et al., 2013).

Based on these indices, the intentionality of great apes' communication gestures has been admitted, notably from Tomasello et al. (1994)'s work on chimpanzee sensitivity to the receiver's attentional state when gesturing, followed by numerous field and lab studies on great apes (see reviews: Byrne et al. 2017; Call and Tomasello 2007; Liebal et al., 2014c). Intentional gestures have been explored recently in monkey species such as macaques (Macaca mulatta, tonkeana, and radiata, (Canteloup et al., 2015a, b; Gupta and Sinha 2019; Deshpande et al., 2018), olive baboons (Papio anubis, Bourjade et al., 2013; Meunier et al., 2013; Molesti et al., 2019), red-capped mangabeys (Cercocebus torquatus, Aychet et al., under review; Maille et al., 2012 ; Schel et al., under review), squirrel monkeys (Saimiri sciureus, Anderson et al., 2010). However, studies of potential intentionality markers accompanying the production of primates' facial expressions are still rare.

Some observational studies seem to indicate the social-dependency of apes' facial expressions. The facial expressions of five gibbon species were shown to last longer when the signaler and the receiver were facing each other in social contexts (Scheider et al., 2016). This social directedness and sensitivity to receiver's attentional state were also observed in orangutans (Pongo pygmaeus) playful facial expressions as they produce more intense play faces when facing a visually-attentive play partner (Waller et al., 2015), and in bonobos (Pan paniscus), who display this facial expression more during social than solitary play, and more in the presence of a visually-attentive recipient (Demuru et al., 2015). Thus, the audience effect supports the communication function of the play faces in these species and their socialdirectedness may reveal both their emotional and intentional use. Moreover, four of siamangs' (Symphalangus syndactylus) facial expressions, mostly performed in combination with tactile or visual gestures, were found to be recipient-directed and accompanied by response waiting or persistence (Liebal et al., 2004c). Assumptions of intentional facial displays were also made for orangutans (Pongo pygmaeus), with the same recipient-directedness and goal-directedness indices found for both gestures and facial expressions (Cartmill and Byrne 2010).

Although observations of apes suggest the dual intentional and emotional use of facial expressions, the question whether monkeys produce facial expressions intentionally to communicate remains open. To our knowledge, even though the facial expressions of numerous catarrhine and platyrrhine monkey species have been described (e.g. Macaca genus: Hesler and Fischer 2007, Hinde and Rowell 1962, Maestripieri 2005, Partan 2002, Thierry et al., 2000; grey-cheeked mangabeys: Lophocebus albigena, Chalmers 1968a; hamadryas baboons: Papio hamadryas, Dube 2013; Talapoins: Miopithecus talapoin, Wolfheim and Rowell 1972; capuchin monkeys: Cebus apella, De Marco and Visalberghi 2007, Visalberghi et al., 2006, Weigel 1979; and see comparative studies of Redican 1975; van Hooff 1967), there is no evidence that non-hominoid monkeys produce facial expressions in association with behavioral markers of intentional communication, as reported for gestures. The investigation of this topic is necessary to fill the gap in understanding both monkeys' facial signal functions and the evolutionary history of intentional communication, which is of prime interest in the study of language origin (Fröhlich et al., 2019, Hauser 1996; Hauser et al., 2002). 
Here, we investigated the facial display repertoire of a relatively little-studied cercopithecid species, red-capped mangabeys (Cercocebus torquatus), and questioned whether these facial displays were dependent of social contexts and accompanied by indices of intentionality. Red-capped mangabeys are semi-terrestrial primates (Mitani et al., 2012) that originate from West African rainforest coastal regions (Cooke 2012; Gautier-Hion et al., 1999; Jones and Sabater-Pi 1968;Orimaye 2017). They have colored hair and skin and white eyelids that contrast with their black face (Figure 1), presumably in accordance with a communication function of facial expressions (Gautier-Hion et al., 1999; Hill 1974; Redican 1975). Their gestural communication has been described recently (Schel et al., under review), and suggests, together with data on their multimodal interactions (Baraud et al., 2016), a wide use of visual signals for communication. Experimental studies highlighted the ability of red-capped mangabeys to use a learnt begging gesture intentionally, as a function of visual attentional state of a human receiver (Aychet et al., under review; Maille et al., 2012). Moreover, spontaneous intra-specific gestures produced by red-capped mangabeys were associated with key-markers of intentional communication (Schel et al., under review). Thus, we hypothesized that the intentional use of visual displays as communication signals by this species would encompass facial expressions. Our first aim was to describe the repertoire of facial displays produced by red-capped mangabeys in social situations, and test how this repertoire depends on individual characteristics. Moreover, in accordance with a presumed communication function, we expected that facial displays would be performed under particular social contexts, while their production in non-social contexts would connote a predominant emotional component underpinning the display. Then, we hypothesized that facial displays would be part of this species' intentional dyadic communication, and thus that they would be accompanied by behavioral markers of intentionality, similarly to gestures.

\section{Figure 1. Contrasts in a red-capped mangabey's facial coloration}

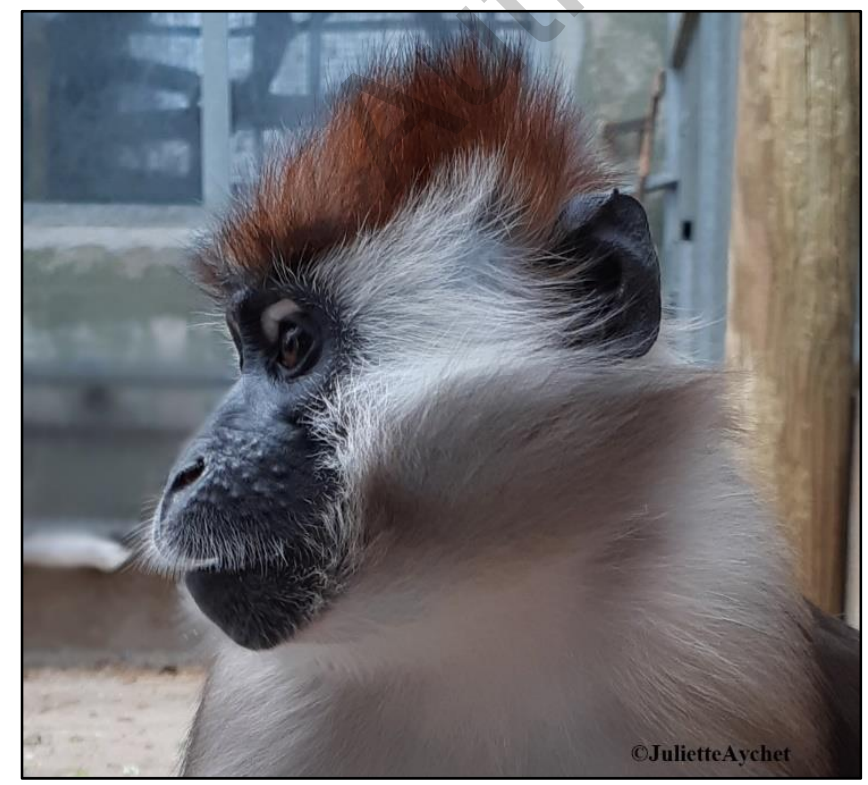




\section{Methods}

\section{Subjects and housing conditions}

Twenty-five red-capped mangabeys (Cercocebus torquatus), born in captivity and housed at the Station Biologique de Paimpont (University Rennes 1, France), were involved in the present study. Subjects were 10 females and 15 males living in social groups composed of two to 13 individuals (Table 1), whose compositions have been stable for at least 8 months. Individuals were classified as juveniles when they were less than 4 years old for females and less than 7 years old for males, based on demographic data on a closely related species, i.e. grey-cheeked mangabeys (Lophocebus albigena) (Chalmers 1968b; Deputte 1992; GautierHion and Gautier 1976). Old adults were also differentiated from middle-aged adults (Bouchet et al., 2012) if they were more than 15 years old, corresponding to the median lifespan of mangabeys in captivity (based on 45 years data from our breeding facility on grey-cheeked and red-capped mangabeys). Kinship was known for every individual in this colony.

Social groups were housed in outdoor-indoor enclosures of different sizes (from 8 to $26.4 \mathrm{~m}^{2}$ for indoor enclosures, 14.7 to $37.2 \mathrm{~m}^{2}$ for outdoor enclosures, and height from $2.5 \mathrm{~m}$ to $4.4 \mathrm{~m}$ ). Individuals were free to move in and out at all time, using connecting tunnels. Indoor enclosure temperature was maintained at $22^{\circ} \mathrm{C}$. Each enclosure was enriched with wood and metal perches, completed with chains or hessian ribbons. The floor of the indoor enclosures was covered with straw and sawdust, while the floor of the outdoor enclosures was covered with cement or bark. Mangabeys were fed twice a day with fresh fruits and vegetables in the morning and with monkey chows in the afternoon. Water was available ad libitum in their indoor enclosures.

\section{Data collection and analyses}

\section{Observations}

A total of 52.22 hours of observations, distributed from the end of January to the end of June 2018, was collected in order to describe facial displays produced by red-capped mangabeys. We applied the individual focal sampling method (Altmann 1974), recording focal videos of about 15 minutes per session (mean session duration $\pm S E=15.67 \pm 0.10 \mathrm{~min}$ ) using a JVC Full HD GZ-RX615 camcorder. Each individual was observed during 8 sessions, for a total of more than 2 hours $(125.33 \pm 0.75 \mathrm{~min})$. These sessions were scheduled semi-randomly, so that all individuals were observed at all times of day (from 9 am to $6 \mathrm{pm}$ ) and at all feeding periods (before first feeding / between two feedings / after second feeding). The experimenter recorded her vocal comments during the video recordings notably to identify individuals interacting with the focal subject.

Videos were then extracted to a computer for further video analyses. Software BORIS v.6.0.6 (Friard and Gamba 2016) was used to play videos and to code each event of facial display and each social interaction involving the focal individual. Because monkeys were free 
to move, the focal individual was sometimes out of sight for few seconds on the camera field. Data were further analyzed taking into account the exact observation durations when the focal subject was visible.

\section{Facial displays}

All the events of facial display produced by the focal individuals were recorded. We defined as "facial displays" all facial movements (i.e. mouth and lips, eyebrows, ears) that could be produced either alone or combined with others, during social interactions or not (Liebal et al., 2014c; van Hooff 1967; Waller and Micheletta 2013). We included all the facial displays that were produced by at least two individuals, discarding idiosyncratic signals.

\section{Contexts of facial displays production}

The social contexts in which facial displays occurred were categorized according to the signaler's and recipient's behavior observed during the 5 seconds before and the 5 seconds after the signal was produced, using the same timeframe as defined for our analysis of behavioral markers of intentionality. The context was considered "non-social" when the signal was not physically directed towards another subject, or when the facial display was accompanied only by non-social behaviors. This yielded nine categories of social and non-social different contexts: affiliative, grooming, alarm, agonistic, submissive, play, sexual, unclear and nonsocial (Table 2). In order to assess the overall importance of each of these nine categories and to weight contextual data accordingly in our analyses, we also established a population-level time budget. To do so, we coded every $10 \mathrm{sec}$ (scan sampling method, Altmann 1974) the social and non-social contexts in which the focal individual was involved, for one session per individual (totalizing 2250 scans for the population).

\section{Dominance relationships}

Dominance relationships between subjects were determined to evaluate their effect on the production of facial expressions. Dominance relationships were based on avoidance behaviors only (see "contact rupture behaviors": Baraud 2007), as physical aggressions were too rare to be used systematically (Easley and Coelho 1991). All avoidance behaviors involving focal subjects were analyzed. Avoidance was defined as turning away from another individual, avoiding an individual by changing direction, avoiding contact with an individual by moving a body part away from the proximity of another individual, fleeing an individual by walking or running in the opposed direction. The total numbers of occurrences of these behaviors were adjusted for 120 minutes observation per focal individual. When at least 3 occurrences were observed for a dyad, we computed the percentage of avoidance of subject A from subject B over the total number of avoidance behaviors between A and B (Zumpe and Michael 1986). When this percentage was above $50 \%$, subject A was considered subordinate to subject B.

\section{Behavioral markers of intentionality}

Using the framework proposed by Townsend et al. (2017), we evaluated whether facial displays produced during dyadic interactions (see "prerequisite") fulfilled the three intentionality criteria of being (i) directed towards a recipient ("recipient-directed"), (ii) produced to reach a particular goal ("goal-directed"), and (iii) if they produce a change in the 
recipient's behavior ("followed by recipient's response"). Behavioral markers corresponding to these criteria and commonly used in gestural studies were coded on a presence / absence basis for each occurrence of facial display (see details in Table 3). Then, intentionality criteria were analyzed at the facial display-level based on the proportion of occurrences accompanied by these behavioral markers (see the statistical analyses section). Some of the markers relative to goal-directedness of signals were yet not included in the present framework, i.e. persistence and elaboration (Cartmill and Byrne 2007; Leavens et al., 2005), because these markers suppose that the observer is knowledgeable about signaler's intention and were so not consistent with this first study of red-capped mangabeys' facial displays. In this line, changes in recipient's behavior that were directed to signaler were considered as estimates of consistent recipient's responses to the facial display.

\section{Inter-observer reliability}

To assess reliability of the video coding, two supplementary observers coded one random session per individual, corresponding to $12.4 \%$ of the total duration of observation and $14.5 \%$ of the total number of facial displays noted (77 occurrences). One observer coded the facial displays and the other coded the intentionality markers and contextual variables. Cohen's Kappa coefficients were computed (Siegel and Castellan 1988), and good levels of agreement (Viera and Garrett 2005) were found for the recognition of the facial displays and their variants $(\kappa=0.77, \mathrm{P}<0.001$ ), all intentionality markers (Directionality: $\kappa=0.94, \mathrm{P}<0.001$; Audience checking: $\kappa=0.73, \mathrm{P}<0.001$; Response waiting: $\kappa=0.69, \mathrm{P}<0.001$; Attentive audience: $\kappa=$ $0.66, \mathrm{P}<0.001$; Response of receiver: $\kappa=0.73, \mathrm{P}<0.001)$ and context categories $(\kappa=0.79, \mathrm{P}$ $<0.001)$.

\section{Statistical analyses}

Given our sample size, non-parametric statistics were used for data analyses. All tests were two-tailed and alpha-level was set at 0.05. We used R. 3.5.0 software (R Core Team 2018) to run all statistical tests. The number of statistical units for each test is stated in the result section using the letter "N".

First, we tested the effects of individual characteristics on the repertoire of facial displays. We analyzed sex and age effects on the production of facial displays using nonparametrical model based on permutation ANOVA (using package $\{1 \mathrm{mPerm}\}$ on R.3.5.0). Models included sex and age categories as fixed factors and were all run ten times, from which average p-values were computed for each fixed factor. When homoscedasticity of variances was not verified, as for the total number of facial displays, the number of "open mouth fully" and yawns of second and third types, age and sex effects were analyzed separately using nonparametrical univariate tests. Kruskal-Wallis one-way analyses of variance by ranks and posthoc Mann-Whitney tests were used to compare numbers of facial displays produced between age categories and Mann-Whitney tests were used to compare numbers of facial displays produced between males and females. 
Second, the social use of facial displays was evaluated based on the contexts in which signals were produced. The number of occurrences in each context was weighted based on the general time-budget (Nonsocial context typically representing $83.29 \%$ of total time; Affiliative: 2.40\%; Agonistic: 0.53\%; Alarm: 0.22\%; Grooming: 5.82\%; Play: 0.62\%; Sexual: 0.09\%; Submissive: $2.13 \%$; Unclear: $4.89 \%$ ). Thus, the weighted frequencies were compared between social and non-social contexts using Wilcoxon signed rank tests, and p-values were adjusted for multiple comparisons using "False Discovery Rate" (FDR) method, controlling the proportion of false significant p-values (Noble 2009). Then, the weighted frequencies of facial displays produced by subjects were compared between the different context categories using Friedman tests and post-hoc Wilcoxon signed rank tests, completed by FDR correction. The same tests were used to analyze the effects of other contextual factors corresponding to the relationship between the signaler and the recipient. We tested the effects of dominance, kinship and age differences on the numbers of facial expressions produced, except for "ears back" and "stick tongue out" for which the numbers of subjects producing them in dyadic interactions were not sufficient $(\mathrm{N}<5)$.

Finally, to assess the intentionality of each type of facial displays, we computed the proportion of occurrences observed in social contexts for which the criteria of intentionality were fulfilled. In order to verify that the markers were not randomly associated to the facial displays, we tested whether the distribution of the cumulative criteria of intentionality differed from a theoretical distribution using Fisher's exact test for count data. Moreover, to complete this assessment of intentionality based on the presence / absence of behavioral markers, we also explored the social-dependency of facial signals by testing if they were more produced in front of attentive than inattentive recipients. We computed the proportion of occurrences in a presence of a visually attentive audience, and compared it to a random distribution using exact binomial tests.

\section{Results}

\section{Repertoire of facial displays}

On a total of 531 occurrences of facial displays recorded, we described six different facial displays, that had all been produced by at least five different signalers (Table 4). These facial displays involved mouth, eyebrows or ear movements and were produced in combination or independently. Some were clearly categorized and stereotyped whereas two of them, "open mouth" and "yawn", seemed graded in relation to their intensity. This potential gradation was reported as different variants of form in the repertoire. We assume that the present repertoire of red-capped mangabeys' facial displays is complete at the population-level. Indeed, while the total number of hours of observation was quite low compared to what may be needed to describe the entire gestural repertoire of a group (e.g. above " 15 hours of active gestures or 150 full days of observation": Hobaiter and Byrne 2011), the cumulative number of described facial displays reached an asymptote (Molesti et al., 2019; Pika et al., 2005) at the $31^{\text {st }}$ session of observation, as no new display was observed up to the final $200^{\text {th }}$ session. 
Individual characteristics affected facial display repertoires (Table 5). Sex had a significant effect on the size of repertoires and numbers of facial displays produced, males producing more facial displays than females (permutation model on repertoire size: $N_{\text {males }}=15$, $N_{\text {females }}=10, P=0.022$; and Mann-Whitney test on number of facial displays produced: $Z=-$ $2.33, P=0.007)$. Age had a tendency to affect repertoire size $\left(N_{\text {juveniles }}=3, N_{\text {middle-aged }}=14, N_{\text {old }}\right.$ $=8, P=0.053)$, as the repertoire of old individuals was significantly smaller than the one of juveniles $(P=0.021)$ and middle-aged adults $(P=0.033)$. Moreover, old individuals also had a tendency to produce fewer facial displays than middle-aged adults (Mann-Whitney test: $Z=$ $2.18, P=0.087)$.

Analyses of data for each facial display separately showed that the numbers of occurrences varied with age and sex of the signaler (Table 5). Juveniles produced significantly more "open mouth" displays than middle-aged (Mann-Whitney test: $Z=2.66, P=0.012$ ) and old adults $(Z=2.67, P=0.012)$. Furthermore, this age effect was found for both "open mouth fully" and "open mouth half" displays. Juveniles produced "open mouth half" more frequently than did middle-aged (permutation model: $P<0.001)$ and old adults $(P<0.001)$, and tended to produce "open mouth fully" more frequently (Mann-Whitney test, comparing juveniles to middle-aged: $Z=2.20, P=0.077$; juveniles to old adults: $Z=1.95, P=0.077$ ). However, numbers of "open mouth" did not differ significantly between sexes (open mouth fully: MannWhitney test, $Z=-1.07, P=0.284$; open mouth half: permutation model, $P=0.120$ ).

We found no effect of age and sex on the production of yawns as a whole (permutation model, sex effect: $P=0.132$; age effect: $P=0.126$, but these individual characteristics affected differently the production of variants of yawns. Although yawns of the first type were not affected by age and sex of subjects (sex effect: $P=0.727$; age effect: $P=0.385$ ) (Table 5), males produced significantly more yawns of the second type than did females (Mann-Whitney test: $Z=-2.68, P=0.007)$. Moreover, subjects' age and sex had both an effect on the production of yawns of the third type, as middle-aged males produced this display more frequently than did other individuals (Mann-Whitney tests, comparing males to females: $Z=-3.039, P=0.002$; middle-aged to juveniles: $Z=-2.12, P=0.034$; old adults to juveniles: $Z=-1.42, P=0.156$; middle-aged to old adults: $Z=1.769, P=0.077$ ).

Individual characteristics did not affect the production of the other facial displays, as age and sex had no significant effects on the numbers of "ears back" (permutation model: age effect: $P=0.432$; sex effect: $P=0.951$ ), "lipsmack" (age effect: $P=0.278$; sex effect: $P=$ 0.820), "raise eyebrows" (age effect: $P=0.862$; sex effect: $P=0.603$ ) or "stick tongue out" (age effect: $P=0.284$; sex effect: $P=0.959$ ) (Table 5).

\section{Contexts of facial display production}

All facial displays were produced in social contexts, but lipsmacks, "stick tongue out" and yawns were also observed in non-social contexts. Lipsmacks were produced significantly more in social than non-social contexts (Wilcoxon signed rank test: $N=23, V=30.5, P=$ $0.003)$, but this was not significant for "stick tongue out" $(N=9, V=7, P=0.124)$, and yawns of second $(N=8, V=18, P=1.000)$ and third types $(N=15, V=61, P=0.978)$. However, 
yawns of first type were produced significantly more in non-social than social contexts $(N=$ $15, V=102.5, P=0.002)$. All other facial displays were produced exclusively in social contexts.

Moreover, the different facial displays were associated with particular social contexts (Figure 2) (Friedman tests: open mouth (all): $N=11, X^{2}=38.59, P<0.001$; open mouth fully: $N=5, X^{2}=35.69, P<0.001$; open mouth half: $N=8, X^{2}=38.59, P<0.001$; raise eyebrows: $N=13, X^{2}=58.60, P<0.001$; ears back: $N=7, X^{2}=25.14, P=0.001$; lipsmack: $N=23, X^{2}=$ 54.95, $P<0.001$; yawns (all): $N=19, X^{2}=81.129, P<0.001$; yawns of first type: $N=15, X^{2}$ $=84.58, P<0.001$; yawns of second type: $N=8, X^{2}=34.66, P<0.001$; and yawns of third type: $\left.N=15, X^{2}=60.21, P<0.001\right)$, except for "stick tongue out" $\left(\mathrm{N}=9, X^{2}=13.61, P=\right.$ 0.092), for which contexts of production were unclear.

Figure 2. Facial displays produced by red-capped mangabeys in relation to non-social and social contexts. Post-hoc Wilcoxon signed rank tests: capital letters (A, B) indicate significant differences with other contextual categories $(P \leq 0.05)$.

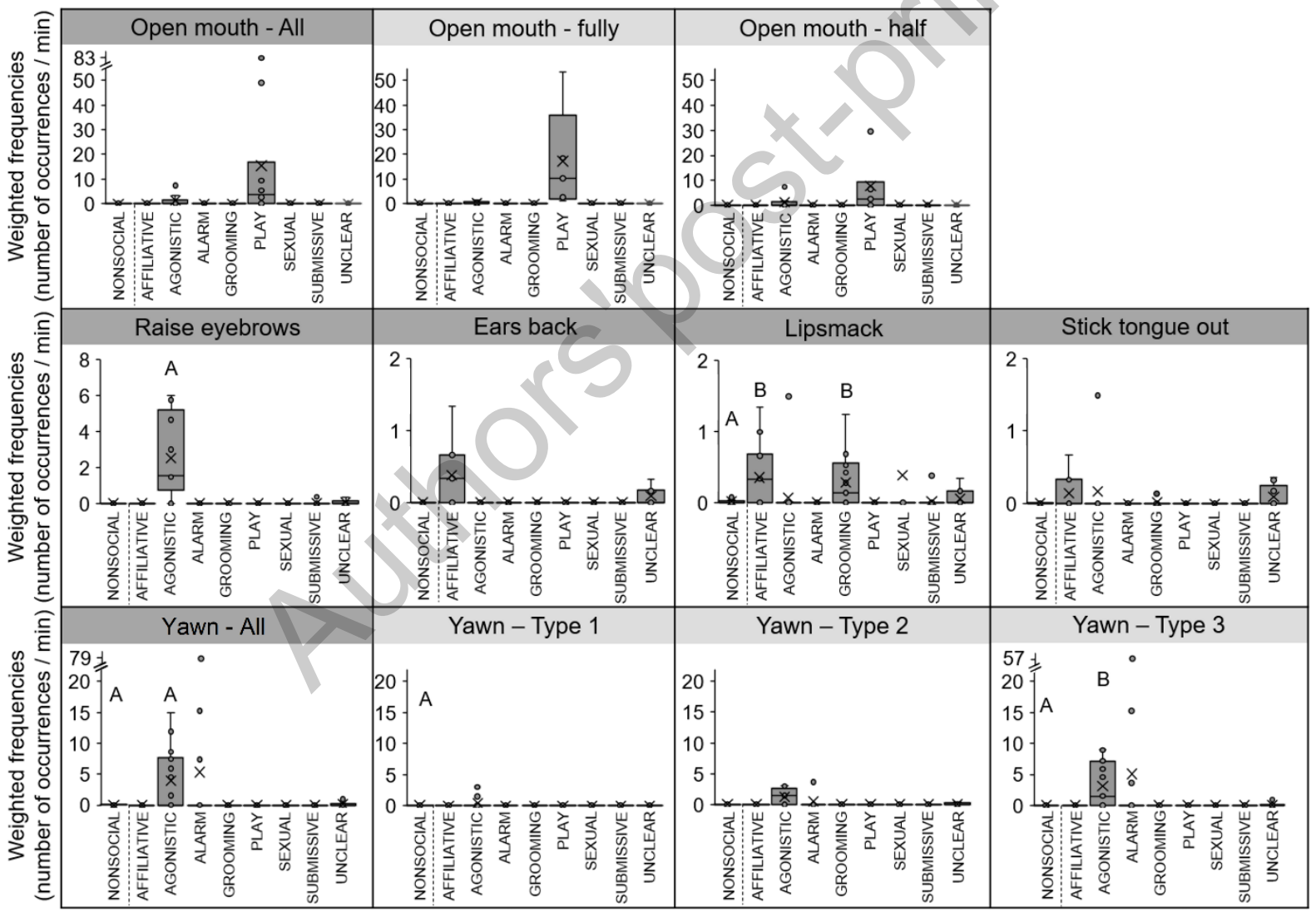

We also evaluated contextual effects of the relationships between signaler and recipient. We found that neither dominance relationship nor kinship affected the numbers of any of the facial expressions produced during dyadic interactions (Wilcoxon signed rank tests: Dominance relationship: $5<N<18,5<V<38, P=1.000$; Kinship: $5<N<18,1<V<65, P>0.375$ ). Age difference between individuals influenced the production of lipsmacking as it was emitted more frequently towards older individuals than towards same-age subjects $(N=18, V=12.5, P$ 
$=0.039)$. Age difference between signaler and recipient had no significant effect on all the other types of facial expressions $(5<N<13,2<V<34, P>0.11)$.

\section{Behavioral markers of intentionality}

All the facial displays of our repertoire, except yawns, were in some cases associated with the behavioral markers of all criteria of intentionality. These markers were indices of social-directedness (i.e. physical directionality and/or audience checking), goal-directedness (i.e. response waiting towards an attentive recipient) and change in recipient's behavior. However, distributions of these behavioral markers differed depending on the facial displays produced in social contexts (Figure 3). These distributions differed significantly from a random theoretical distribution for "open mouth" (all variants summed: $N=138, P=0.001$ ), "open mouth fully" $(N=64, P<0.001)$, "open mouth half" $(N=74, P<0.001)$, "lipsmack" (Fisher's exact test: $N=81, P<0.001$ ), yawns (all types summed: $N=98, P<0.001$ ), as well as for the third type of yawns (type $1: N=5, P=0.211$; type 2 : $N=14, P=0.211$; type $3: N=63, P<$ $0.001)$. The highest level of association with intentional cues was for "open mouth fully" and "half open" displays that were generally accompanied by markers of all criteria of intentionality (95/138 occurrences). The distribution of the cumulative behavioral markers did not differ from a random distribution for "raise eyebrows", "ears back", and "stick tongue out". Lipsmacks and yawns were sparsely or never displayed in association with markers of goal-directedness (20/81 occurrences for lipsmacks, and 2/98 occurrences for yawns). However, lipsmacks were mainly produced in the direction of a recipient ( $71 / 81$ occurrences), whereas all types of yawns seemed disentangled from dyadic interactions (85/98 occurrences non directed).

Figure 3. Distributions of the cumulative intentionality markers accompanying facial displays. Percentages are computed on total numbers of occurrences observed in social contexts $(N)$. Comparisons with random theoretical distributions were computed using Fisher's exact tests. $n s: P>0.05 ; *: P \leq 0.05$; **: $P<0.01$; ***: $P<0.001$.

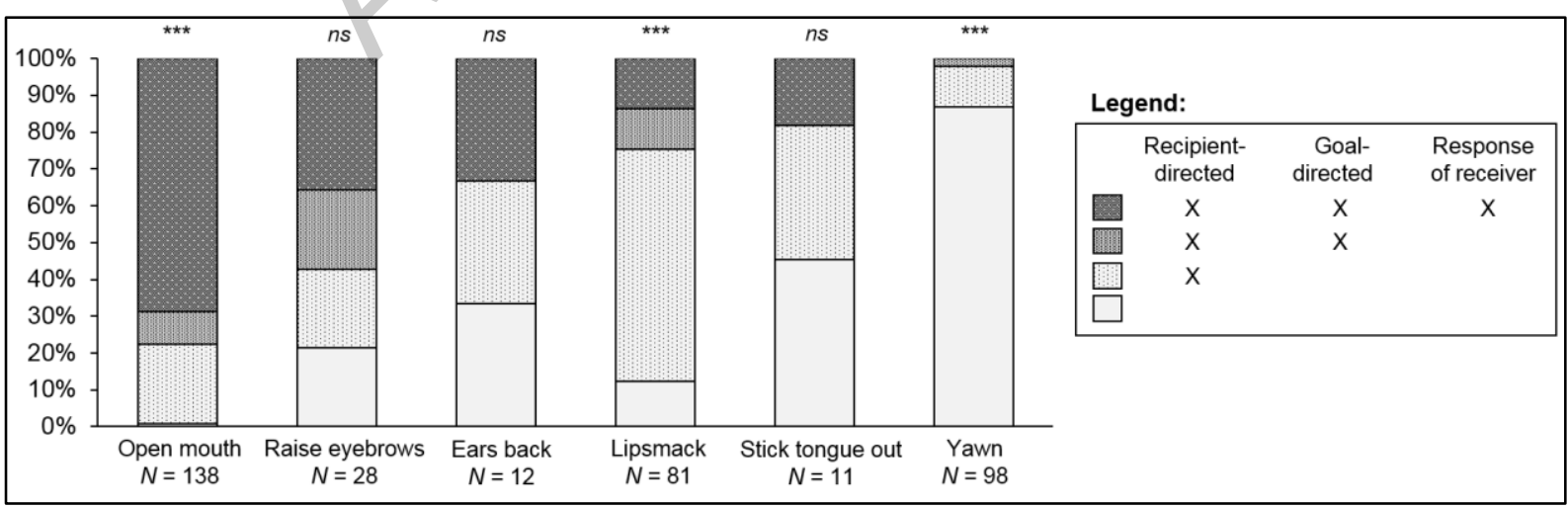

Finally, we found that "open mouth" and "raise eyebrows" were mainly displayed in the presence of a visually attentive recipient (Exact binomial tests: open mouth (all): $N=134, P<$ 0.001; open mouth fully: $N=64, P<0.001$; open mouth half: $N=70, P<0.001$; raise eyebrows: 
$N=19, P<0.001$ ), and that yawns of second and third type were produced less in the presence of a visually attentive recipient (yawns (all): $N=88, P<0.001$; yawns of second type: $N=12$, $P=0.010$; and third type: $N=59, P<0.001$ ), and it was a tendency for yawns of first type ( $N$ $=5, P=0.063)$ (Figure 4). We found no significant difference with a theoretical distribution for "ears back" $(N=4, P=0.188)$, "lipsmack" $(N=64, P=1.000)$, and "stick tongue out" ( $N$ $=5, P=1.000)$.

Figure 4. Proportion of occurrences in the presence of a visually attentive recipient. Percentages are computed on total numbers of occurrences observed in social contexts and only when recipient was visible $(N)$. Comparisons with random theoretical distributions were computed using exact binomial tests. $n s: P>0.05$; **: $P<0.01$; ***: $P<0.001$.

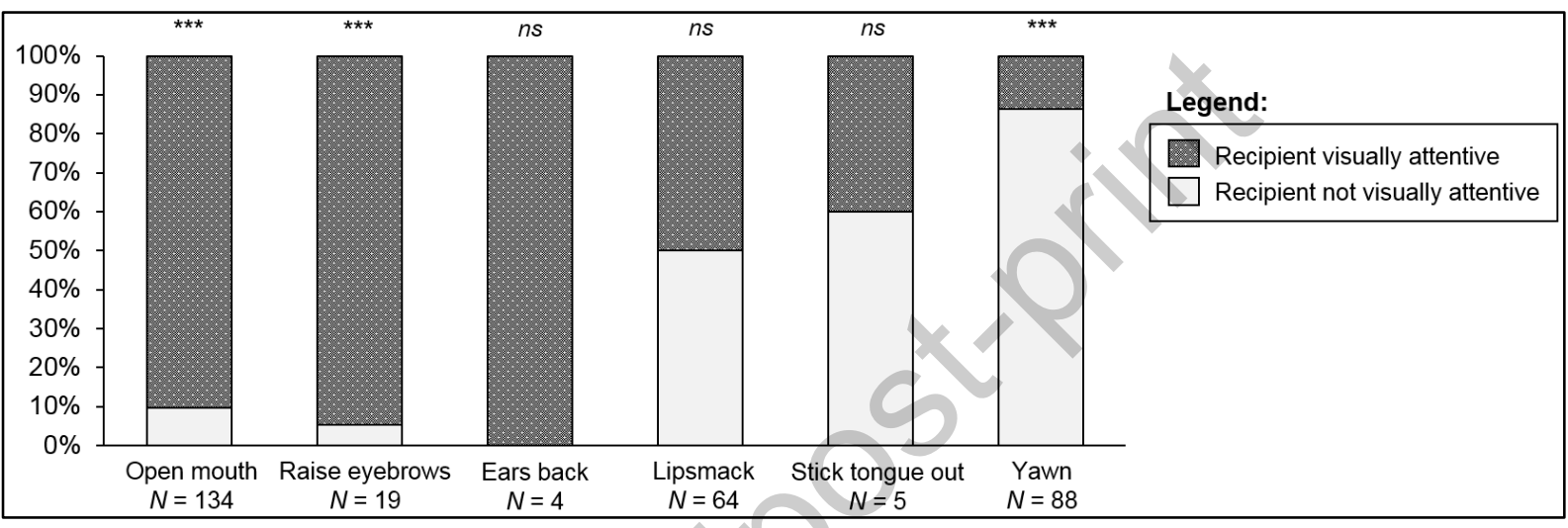

\section{Discussion}

This study explored the repertoire of six facial displays of a captive population of redcapped mangabeys, and tested whether these displays were produced socially and accompanied by indices of intentional communication. This preliminary assessment of first-order intentionality in mangabeys' facial displays was based on behavioral markers similar to those used in gestural studies, to evaluate whether signals were (i) directed towards a recipient, (ii) produced in order to reach a specific goal and (iii) led to a change in the recipient's behavior (Townsend et al., 2017). The social condition of mangabeys' facial displays, as well as the effects of individual characteristics on the repertoire, supports their communication function. The playful "open mouth" displays were produced exclusively in social contexts and in most cases in the direction of an attentive recipient, with all defined markers of intentional communication. We discuss below the significance of these results regarding the potential intentionality of these displays, given the current limitations of the behavioral method used to assess first-order intentionality in animal communication (Graham et al. 2019). Although other cognitive mechanisms may explain our observations, the present results constitute a first step to address the potential intentionality of red-capped mangabeys' facial displays, particularly the "open mouth". While not meeting criteria for goal-directed signals for all occurrences, other facial displays ("raise eyebrows", "ears back", lipsmacks and "stick tongue out") except yawns 
were at least recipient-directed in most cases. Finally, yawns seemed not associated with dyadic communication, and thus did not fulfill the defined criteria for intentional communication. Interestingly, these displays presented different variants of intensity, which were presumably associated with different functions.

We described six facial displays produced by red-capped mangabeys, which involve movements of the ears, eyebrows or mouth, and can be produced in combination or independently one from the other. One noticeable point of the present repertoire is the description of unitary ear displays used socially by red-capped mangabeys. While non-human primates' ear musculature is controlled by facial nerves (Müri 2016), few studies of facial displays describe ear movements (but see in rhesus and long-tailed macaques, Macaca mulatta and fascicularis : Chance et al., 1977; Hinde and Rowell 1962; Partan 2002). Although most facial displays of the repertoire are discrete, we distinguished variants for two of them, corresponding to different intensities of mouth displays. The repertoire size and this possible gradualness of the morphology of some facial displays suggest that red-capped mangabeys' communication relies strongly on complex visual cues (Dobson 2009; Freeberg et al., 2012).

Thus, the "open mouth" displays, highly related to play contexts, appeared graded. Some facial displays are indeed graded signals that can be associated with different motivations of the signaler (Marler 1965; Parr et al., 2005; Preuschoft and van Hooff 1996; Waller and Micheletta 2013). In primates, the variants "open mouth fully" and "half" have been largely described as playful facial displays ( Chevalier-Skolnikoff 1994; van Hooff 1967). Moreover, subjects' age influenced the production of "open mouth fully" and "half", as younger subjects were involved in playful interactions more frequently and were possibly more emotionally involved in play than adults (Demuru et al., 2015). Although primate gestures are used in variable contexts (Byrne et al., 2017; Call and Tomasello 2007; Hobaiter and Byrne 2013; Liebal et al., 2014c), the fact that facial displays are more context-specific allows us to hypothesize that their function is to help elucidate the meaning of associated signals used in multimodal communication. These facial displays may act as "metacommunicative signals" (Altmann 1967; Bateson 1955), notably because play might involve agonistic-like gestures (Demuru et al., 2015; Palagi 2008; Waller and Cherry 2012).

Red-capped mangabeys generally produced "open mouth fully" and "open mouth half" in association with all previously defined behavioral markers of intentionality, and significantly more in situations when the receiver was visually attentive. Therefore, our results on red-capped mangabeys' directed "open mouth" are consistent with previous observations of great apes. Bonobos' (Pan paniscus: Demuru et al., 2015) and orangutans' (Pongo pygmaeus: Waller et al., 2015) homologous facial displays were suggested to be dependent on audience attentional state, indicating that these facial expressions are not an automatic response to play.

However, we should be careful before drawing the conclusion that these "open mouth" displays are produced intentionally, given some alternative explanations to audience effect. For instance, the production of "open mouth" preferentially in front of an attentive recipient could be the result of a learnt discrimination. Individuals may be more likely to produce a facial display in these conditions because they have learnt that seeing the face of a recipient is necessary to obtain a response from their signal (Graham et al., 2019). Moreover, the social use 
of "open mouth" and the sensitivity to the recipient's attentional state cannot rule out an emotional-based production of these displays. Eye gaze is an emotional stimulus in primates (Emery 2000), and arousal is prone to be higher in the presence of others compared to alone (Zajonc 1965). Thus, these factors could induce changes in the signaler's emotional state, resulting in the production of the facial expressions. Besides, observations in apes suggest that the production of play faces has a strong emotional component. This expressions can be observed during bonobos' (Pan paniscus) solitary play (Demuru et al., 2015), and the example of a female gorilla (Gorilla gorilla) hiding her play face (Tanner and Byrne 1993) suggests that she was not able to inhibit this facial display, as it is the case of humans experiencing intense emotions (Porter et al., 2012). We found concomitant markers of other criteria of intentional communication (i.e. waiting for a response from the signaler and recipient's consistent behavioral response) accompanying red-capped mangabeys' "open mouth", but one particular limit of the present observations is that "response waiting" should be cautiously interpreted as a goal-directedness marker per se (Graham et al., 2019; Liebal et al., 2014b). As a first insight in the intentionality of facial displays in red-capped mangabeys, the present framework about "goal-direction" did not include markers related to goal-dependent cessation of communication or persistence and elaboration, because these aspects of signal's "aboutness" require that the observer is knowledgeable of the signal function and thus presumed signaler's intention displaying it. Thus, we must remain cautious when concluding about the possible intentionality of the signals studied, given that criteria of recipient-directedness and goal-directedness were both assessed based on markers related to visual attention only. Moreover, while analyzing intentionality at the signal-level, this study did not address yet the question of inter-individual variability in intentional communicative facial displays. In this sense, the present results will need to be supplemented by further investigations of the goal-directedness of "open mouth fully" and "half", which presumably corresponds to an invitation to play or to maintain a playful interaction. We believe that a multimodal approach would be beneficial in this regard, addressing goal-persistence by taking into account associated vocalizations and gestures.

Overall, there are current validity limitations in the behavioral method used to assess first-order intentionality in animal communication (see the above-mentioned examples of other cognitive processes possibly underlying the behaviors identified as intentionality markers). The framework proposed by Townsend et al. (2017) has the advantage to be widely applicable to diverse species and communication modalities, although it does not permit to conclude with certainty that signals are intentionally produced. Graham and colleagues (2019) suggested some perspectives in light of this methodological problem, such as experimentally address secondorder intentionality (which implies mental-state attribution, see Dennett 1983), or complete observational studies with valid measures of arousal during signal production. Until such approaches are applicable, behavioral assessment of first-order intentionality still permits to gather meaningful information, such as the present results, which we believe constitute a first step in assessing the intentionality of red-capped mangabey facial displays, particularly for "open mouth".

Other facial displays "raise eyebrows", "ears back", lipsmacks and "stick tongue out" appeared only partially accompanied by defined behavioral markers of intentionality. However, these displays were at least recipient-directed in most of the cases, thus indicating their 
communicative function (Call and Tomasello 1994; Leavens et al., 1996). Eyebrow raising and ears back were exclusively produced in social contexts, i.e. agonistic and affiliative contexts respectively, and mostly directed to a visually attentive recipient. Lipsmacks were produced more in social than non-social contexts, particularly in affiliative and grooming situations, but not more in front of an attentive than an inattentive recipient, as found for "stick tongue out". While lipsmacks' production was not dependent on recipient's visual attention, we may hypothesize that this signal can also be acoustically perceived (as the "audible smacking sound" produced by macaques: Maestripieri and Wallen 1997; Maestripieri 2005), and therefore visual attention would not be necessary. We note that most of the above-cited facial displays described, except "stick tongue out", were preferentially or exclusively produced in social contexts. Lipsmacks were produced in affiliative and grooming contexts, as found for instance in olive baboons (Papio anubis: Easley and Coelho 1991), but also in non-social contexts, especially during auto-grooming. This enabled us to hypothesize that lipsmacking may be an automatic response to grooming actions and, as for non-social production of yawns, might indicate a prominent emotional component driving the production of this facial display.

Yawns, as opposed to the other facial displays, seem to be disentangled from dyadic interactions, as even in social contexts we found almost no signs of recipient-directed use. The high frequency of yawns in non-social context is in agreement with the hypothesis that yawns are strongly linked to internal states of the signaler (Deputte 1994). Moreover, regarding their production in social conditions, yawns may have an informative function, for conspecifics, on the signaler's emotional state during agonistic and alarm contexts (Bolwig 1959; Deputte 1994). An interesting point concerning this particular display lies in the relationship between its form and function, as red-capped mangabeys produced different types of yawns, with regard to mouth opening and teeth uncovering, in different contexts. These variations are known and characterized for grey-cheeked mangabeys (Lophocebus albigena: Deputte 1994), as well as for macaque species (Macaca fascicularis: Deputte 1994; Zannella et al., 2017), geladas (Theropithecus gelada: Palagi et al., 2009) and chimpanzees (Pan troglodytes: Vick and Paukner 2010).

Yawns of the first type, with mouth less open, were used only in non-social contexts and might correspond to physiological regulators during transition between activity and resting or during feeding anticipation (Deputte 1978). Some yawns of the second and third types, with mouth more open and teeth more visible were associated with alarm calls, as described also for grey-cheeked mangabeys (Lophocebus albigena: Deputte 1994), apparently because of high arousal and social tension. Moreover, yawns of the third type were mainly produced in agonistic contexts, as visible canines are hypothesized to play the role of threat or pre-threat (Altmann 1967; Redican 1975). Yawns of the third type were produced more frequently by middle aged and old adult males, while individual characteristics did not affect the production of yawns of the first type. In our sample, the males were not equally distributed in the social groups, most of them living in all-male groups. However, as sex influenced some variants of yawns and not the others, we assume that male group membership did not bias the analysis of the effect of sex on facial display repertoire. These results on sex effects are consistent with the hypothesis of a threat value of the yawns with visible canines (Leone et al., 2014; Zannella et al., 2017), particularly because red-capped mangabeys exhibit an important sexual dimorphism in canine 
size that becomes evident with sexual maturity (Deputte 1986; Hill 1974). This hypothesis is supported by similar sexual differences of yawn production by macaque species (Macaca fuscata and tonkeana: Zannella et al., 2017), taken that this difference was not found for primate species such as lemurs (Propithecus verreauxi and Lemur catta: Zannella et al., 2015) or humans (Homo sapiens: Schino and Aureli 1989), with absent or slight sexual dimorphism in canine-size. Moreover, the age effect on yawn production may be associated with testosterone level changing with sexual maturity since testosterone was correlated with yawn production in rhesus macaques (Macaca mulatta: Phoenix and Chambers 1982; Robinson et al., 1975; Wallen and Goy 1977). The relationship between yawn morphological variability and function, highlighted by the contexts of production and by the effect of individual characteristics, is in agreement with previous results for geladas (Theropithecus gelada: Leone et al., 2014). In macaques, this was associated with communication redundancy observed in species showing more tolerant social styles (Zannella et al., 2017) which also exhibit larger meaningful communicative repertoires (Dobson 2012).

Moreover, we found no dominance or kinship effects on any of the facial expressions displayed, presumably in relation with the sociality of red-capped mangabeys, which have been shown to adopt both despotic and egalitarian behaviors (Dolado and Beltran 2012). Despite a steep hierarchy within their groups, red-capped mangabeys have indeed relatively dynamic dominance relationships (Dolado and Beltran 2011) with some propensity to counter-attack, as do tolerant macaque species (de Waal and Luttrell 1989; Thierry 2007).

\section{Conclusion}

In sum, the repertoire of red-capped mangabeys' facial displays is composed by six different displays that could be graded in intensity. We characterized the social-dependent production of facial expressions by red-capped mangabeys, and brought to light behavioral indices of intentionality accompanying facial displays. Particularly, playful "open mouth" appeared strongly associated with some intentionality indices, as previously noticed in ape species. We believe that the present repertoire provides a basis for further research on function and intentionality of red-capped mangabeys' facial expressions. As the gestural, vocal and facial signals are now described in this species, we also believe that it will constitute a useful tool for a multimodal approach for the study of catarrhine monkeys' intentional communication, a key feature for evolutionary research on language origins. 
Table 1. Characteristics of the red-capped mangabeys.

\begin{tabular}{lllll}
\hline Social group & Subject & \multicolumn{1}{c}{ Sex } & Date of birth & Age Category \\
\hline I. & Bell & Female & $31 / 03 / 2002$ & Old adult \\
& Chipie & Female & $28 / 06 / 1992$ & Old adult \\
& Chipse & Female & $03 / 01 / 2006$ & Middle-aged \\
& Gofrette & Female & $08 / 11 / 1996$ & Old adult \\
& Joly & Female & $22 / 10 / 2000$ & Old adult \\
& Julie & Female & $08 / 05 / 2004$ & Middle-aged \\
& Kargi & Male & $19 / 05 / 2005$ & Middle-aged \\
& Litchi & Male & $20 / 04 / 2015$ & Juvenile \\
& Maillette & Female & $29 / 12 / 2009$ & Middle-aged \\
& Many & Female & $14 / 08 / 2008$ & Middle-aged \\
& Pouët & Male & $14 / 03 / 2015$ & Juvenile \\
& Triskelle & Female & $21 / 04 / 2015$ & Juvenile \\
& Zunie & Female & $03 / 07 / 1987$ & Old adult \\
III. & Kamel & Male & $07 / 09 / 2010$ & Middle-aged \\
& Roby & Male & $18 / 11 / 2010$ & Middle-aged \\
& Bandit & Male & $15 / 06 / 1991$ & Old adult \\
IV. & Coët & Male & $31 / 08 / 2011$ & Middle-aged \\
& Tips & Male & $10 / 07 / 2011$ & Middle-aged \\
& Carillon & Male & $02 / 04 / 2007$ & Middle-aged \\
& Elky & Male & $06 / 11 / 2009$ & Middle-aged \\
& George & Male & $05 / 06 / 2006$ & Middle-aged \\
V. & Pirate & Male & $17 / 10 / 1992$ & Old adult \\
& Isba & Male & $20 / 04 / 2004$ & Middle-aged \\
& Lenni & Male & $07 / 10 / 2006$ & Middle-aged \\
& Marti & Male & $16 / 10 / 1998$ & Old adult \\
\hline
\end{tabular}


Table 2. Contexts of production of facial displays.

\begin{tabular}{|c|c|}
\hline Context & Associated behaviors \\
\hline Affiliative & $\begin{array}{l}\text { Physical proximity between subjects (at less than one arm length), calm approach of } \\
\text { recipient or gentle physical contact }\end{array}$ \\
\hline Grooming & Grooming, tactile examination \\
\hline Alarm & $\begin{array}{l}\text { Production of alarm calls by the signaler (i.e. so-called Whoop-gobble and WaHoo } \\
\text { calls - Bouchet et al., 2010) }\end{array}$ \\
\hline Agonistic & $\begin{array}{l}\text { Physical aggression of recipient by signaler (biting, beating, rough manipulation), } \\
\text { flight or avoidance of signaler by recipient, or intergroup conflict in which signaler } \\
\text { and recipient were in different social groups }\end{array}$ \\
\hline Submissive & Flight or avoidance of recipient by signaler \\
\hline Social play & $\begin{array}{l}\text { Play-fight, rough or gentle (involving manual fighting, biting, gentle or rough } \\
\text { touching and grabbing), or locomotor-rotational play (play with few physical } \\
\text { contacts, but involving pursuits, jumps, saltos) }\end{array}$ \\
\hline Sexual & Touching, smelling, licking genital parts or mounting \\
\hline Unclear & $\begin{array}{l}\text { Behaviors accompanying the signal were not sufficient to classify the context, or the } \\
\text { interaction could be classified in several categories. }\end{array}$ \\
\hline Non-social & $\begin{array}{l}\text { The signal was not physically directed towards another subject, or the facial display } \\
\text { was accompanied only by non-social behaviors, directed towards the environment } \\
\text { (foraging, manipulation, visual, olfactory or gustative exploration of the } \\
\text { environment) or self-directed (self-grooming, feeding, peeing or defecation, sleep or } \\
\text { rest, solitary play). }\end{array}$ \\
\hline
\end{tabular}


Table 3. Behavioral markers used to assess intentionality of facial displays, based on criteria adapted from Townsend et al. (2017).

\begin{tabular}{|c|c|c|c|}
\hline Criteria & $\begin{array}{c}\text { Behavioral } \\
\text { markers }\end{array}$ & Description & $\begin{array}{c}\text { References from gestural } \\
\text { studies }\end{array}$ \\
\hline $\begin{array}{l}\text { Prerequisite for } \\
\text { the present } \\
\text { framework }\end{array}$ & $\begin{array}{l}\text { Presence of an } \\
\text { audience } \\
\text { and dyadic } \\
\text { context }\end{array}$ & $\begin{array}{l}\text { The facial display is produced in the } \\
\text { presence of an audience, i.e. with other } \\
\text { individuals in the same enclosure. } \\
\text { Moreover, we took into account only } \\
\text { occurrences for which the observer } \\
\text { identified a unique putative recipient. }\end{array}$ & $\begin{array}{l}\text { e.g. Leavens et al., 1996; for } \\
\text { review: Liebal et al., 2014b }\end{array}$ \\
\hline \multirow[t]{2}{*}{$\begin{array}{l}\text { (i.) Recipient- } \\
\text { directed signal }\end{array}$} & Directionality & $\begin{array}{l}\text { At least one of the following postural or } \\
\text { physical markers of directionality } \\
\text { accompanied the facial display: head or } \\
\text { body is oriented towards the recipient; a } \\
\text { movement is produced in the direction } \\
\text { of the recipient; the signaler is } \\
\text { approaching the recipient; signaler and } \\
\text { recipient are in physical contact. }\end{array}$ & $\begin{array}{l}\text { e.g. Schel et al., under review; } \\
\text { Tomasello et al., 1985, 1994; } \\
\text { Leavens and Hopkins 1998; } \\
\text { Leavens et al., 2004a; Liebal } \\
\text { et al, 2004b, 2014b; Call and } \\
\text { Tomasello } 2007\end{array}$ \\
\hline & $\begin{array}{l}\text { Audience } \\
\text { checking }\end{array}$ & $\begin{array}{l}\text { During the } 5 \text { seconds preceding the } \\
\text { production of the facial display, the } \\
\text { signaler looks in the direction of the } \\
\text { recipient (recipient is more or less } 45^{\circ} \\
\text { in front of the signaler's face). }\end{array}$ & $\begin{array}{l}\text { e.g. Schel et al., under review; } \\
\text { Genty et al., 2009; Hobaiter } \\
\text { and Byrne } 2011\end{array}$ \\
\hline $\begin{array}{l}\text { (ii.) Goal- } \\
\text { directed signal }\end{array}$ & $\begin{array}{l}\text { Response } \\
\text { waiting }\end{array}$ & $\begin{array}{l}\text { The signaler maintains a look in the } \\
\text { direction of the recipient for at least } 1 \\
\text { second after the facial display was } \\
\text { produced (recipient is more or less } 45^{\circ} \\
\text { in front of signaler's face), }\end{array}$ & $\begin{array}{l}\text { e.g. Schel et al., under review; } \\
\text { Tomasello et al., 1985, 1994; } \\
\text { Pika et al., 2003; Liebal et al., } \\
\text { 2004c; Call and Tomasello } \\
\text { 2007; Cartmill and Byrne } \\
\text { 2010; Hobaiter and Byrne } \\
\text { 2011; Roberts et al., 2012, } \\
\text { 2014; Graham et al., 2017; } \\
\text { Molesti et al., 2019 } \\
\text { e.g. Pika et al., 2003; Genty et } \\
\text { al., } 2009\end{array}$ \\
\hline $\begin{array}{l}\text { (iii.) Signal } \\
\text { followed by } \\
\text { recipient's } \\
\text { response }\end{array}$ & $\begin{array}{l}\text { Recipient's } \\
\text { behavioral } \\
\text { change or } \\
\text { signaling }\end{array}$ & $\begin{array}{l}\text { Within the } 5 \text { seconds following the } \\
\text { facial display, the receiver changes } \\
\text { his/her behavior compared to before the } \\
\text { signal, interacting socially with the } \\
\text { signaler or producing a communication } \\
\text { signal (vocalization, gesture or facial } \\
\text { expression) directed towards the } \\
\text { signaler. }\end{array}$ & $\begin{array}{l}\text { e.g. Liebal et al., 2004a, b, } \\
\text { 2006; Roberts et al., 2014; } \\
\text { Schel et al., under review }\end{array}$ \\
\hline
\end{tabular}


Table 4. Facial displays of red-capped mangabeys and sample size. $N b$ : Number of occurrences; $N$ : Number of signalers

\begin{tabular}{|c|c|c|c|c|}
\hline Facial display & Variants & Description & $\mathrm{Nb}$ & $N$ \\
\hline \multirow[t]{2}{*}{ Open mouth } & Fully & $\begin{array}{l}\text { Signaler opens his/her mouth completely, } \\
\text { uncovering upper and lower teeth. }\end{array}$ & 64 & 5 \\
\hline & Half & $\begin{array}{l}\text { Signaler opens his/her mouth half or slightly, } \\
\text { forming an oval shape with the lips, teeth covered } \\
\text { or slightly visible. }\end{array}$ & 74 & 11 \\
\hline Raise eyebrows & - & $\begin{array}{l}\text { Signaler raises his/her eyebrows, enlarging the } \\
\text { white part of eyelids. }\end{array}$ & 28 & 13 \\
\hline Ears back & - & $\begin{array}{l}\text { Signaler puts his/her ears backwards, stretching } \\
\text { the upper part of his/her face. }\end{array}$ & 12 & 7 \\
\hline Lipsmack & - & $\begin{array}{l}\text { Signaler sticks out his/her tongue and moves it } \\
\text { between the lips with rapid repeated movements. }\end{array}$ & 112 & 23 \\
\hline Stick tongue out & - & $\begin{array}{l}\text { Signaler sticks his/her tongue out and retracts it } \\
\text { briefly (not repeated). }\end{array}$ & 15 & 9 \\
\hline \multirow[t]{4}{*}{ Yawn } & Type 1 & $\begin{array}{l}\text { Signaler yawns by half opening mouth, forming } \\
\text { an oval shape, teeth covered by lips. }\end{array}$ & 55 & 15 \\
\hline & Type 2 & $\begin{array}{l}\text { Signaler yawns by half opening mouth, canines } \\
\text { uncovered. }\end{array}$ & 30 & 8 \\
\hline & & $\begin{array}{l}\text { Signaler yawns by opening mouth fully and } \\
\text { uncovering all teeth. }\end{array}$ & 116 & 15 \\
\hline & $\begin{array}{l}\text { Non- } \\
\text { visible }\end{array}$ & $\begin{array}{l}\text { Signaler yawns, but type of yawn is not visible by } \\
\text { the observer. }\end{array}$ & 25 & 5 \\
\hline
\end{tabular}


Table 5. Facial displays produced depending on individual characteristics. $N$ : Number of subjects; $n$ : Number of subjects of each age and sex category, which produced the facial display; *: Kruskal-Wallis one-way analysis of variance by ranks and Mann-Whitney tests; others: nonparametrical mixed model based on permutation ANOVA. $a$ and $b$ indicate respectively significant age and sex effects $(\mathrm{P} \leq 0.05)$

\begin{tabular}{|c|c|c|c|c|c|c|c|c|c|c|c|c|c|c|}
\hline \multirow{2}{*}{$\begin{array}{c}\text { Sex and } \\
\text { age groups }\end{array}$} & \multirow[t]{2}{*}{$N$} & \multirow{2}{*}{$\begin{array}{l}\text { Reper- } \\
\text { toire } \\
\text { size } \\
(a+b)\end{array}$} & \multicolumn{12}{|c|}{ Median numbers of facial display occurrences $\pm I Q R(n)$} \\
\hline & & & $\begin{array}{c}\text { Total* } \\
\text { (b) }\end{array}$ & $\begin{array}{c}\text { Open } \\
\text { mouth } \\
- \text { All* } \\
(a)\end{array}$ & $\begin{array}{c}\text { Open } \\
\text { mouth } \\
\text { fully* } \\
(a)\end{array}$ & $\begin{array}{c}\text { Open } \\
\text { mouth } \\
\text { half } \\
(a)\end{array}$ & $\begin{array}{c}\text { Raise } \\
\text { eye- } \\
\text { brows }\end{array}$ & $\begin{array}{l}\text { Ears } \\
\text { back }\end{array}$ & $\begin{array}{c}\text { Lip- } \\
\text { smack }\end{array}$ & $\begin{array}{c}\text { Stick } \\
\text { tongue } \\
\text { out }\end{array}$ & $\begin{array}{c}\text { Yawn - } \\
\text { All }\end{array}$ & $\begin{array}{c}\text { Yawn } \\
\text { Type } 1\end{array}$ & $\begin{array}{c}\text { Yawn } \\
\text { Type 2* } \\
\text { (b) }\end{array}$ & $\begin{array}{c}\text { Yawn } \\
\text { Type 3* } \\
(a+b)\end{array}$ \\
\hline Males & 15 & $5 \pm 2$ & $\begin{array}{l}22.50 \\
\pm 33.89\end{array}$ & $\begin{array}{l}0.00 \\
\pm 4.73 \\
(6)\end{array}$ & $\begin{array}{l}0.00 \\
\pm 0.92 \\
(4)\end{array}$ & $\begin{array}{l}0.00 \\
\pm 4.73 \\
(6)\end{array}$ & $\begin{array}{l}0.95 \\
\pm 2.97 \\
(8)\end{array}$ & $\begin{array}{l}0.00 \\
\pm 0.98 \\
(6)\end{array}$ & $\begin{array}{l}2.86 \\
\pm 4.86 \\
(14)\end{array}$ & $\begin{array}{l}0.00 \\
\pm 0.98 \\
(6)\end{array}$ & $\begin{array}{l}10.40 \\
\pm 11.79 \\
(14)\end{array}$ & $\begin{array}{l}1.91 \\
\pm 3.91 \\
(10)\end{array}$ & $\begin{array}{l}0.95 \\
\pm 3.67 \\
(8)\end{array}$ & $\begin{array}{l}5.09 \\
\pm 8.58 \\
(13)\end{array}$ \\
\hline Females & 10 & $3 \pm 4$ & $\begin{array}{l}10.04 \\
\pm 10.86\end{array}$ & $\begin{array}{l}0.48 \\
\pm 2.48 \\
(5)\end{array}$ & $\begin{array}{l}0.00 \\
\pm 0.00 \\
(1)\end{array}$ & $\begin{array}{l}0.48 \\
\pm 1.98 \\
(5)\end{array}$ & $\begin{array}{l}0.48 \\
\pm 1.23 \\
(5)\end{array}$ & $\begin{array}{l}0.00 \\
\pm 0.00 \\
(1)\end{array}$ & $\begin{array}{l}4.84 \\
\pm 3.57 \\
(9)\end{array}$ & $\begin{array}{l}0.00 \\
\pm 0.97 \\
(3)\end{array}$ & $\begin{array}{l}0.97 \\
\pm 5.30 \\
(5)\end{array}$ & $\begin{array}{l}0.97 \\
\pm 4.35 \\
(5)\end{array}$ & $\begin{array}{l}0.00 \\
\pm 0.00 \\
(0)\end{array}$ & $\begin{array}{l}0.00 \\
\pm 0.76 \\
(2)\end{array}$ \\
\hline Juveniles & 3 & $4 \pm 4$ & $\begin{array}{l}43.52 \\
\pm 62.24\end{array}$ & $\begin{array}{l}38.58 \\
\pm 58.04 \\
(3)\end{array}$ & $\begin{array}{l}13.85 \\
\pm 40.92 \\
(2)\end{array}$ & $\begin{array}{l}24.13 \\
\pm 17.72 \\
(3)\end{array}$ & $\begin{array}{l}1.05 \\
\pm 2.97 \\
(2)\end{array}$ & $\begin{array}{l}0.00 \\
\pm 0.00 \\
(0)\end{array}$ & $\begin{array}{l}0.00 \\
\pm 1.98 \\
(1)\end{array}$ & $\begin{array}{l}0.00 \\
\pm 2.10 \\
(1)\end{array}$ & $\begin{array}{l}0.00 \\
\pm 1.05 \\
(1)\end{array}$ & $\begin{array}{l}0.00 \\
\pm 1.05 \\
(1)\end{array}$ & $\begin{array}{l}0.00 \\
\pm 0.00 \\
(0)\end{array}$ & $\begin{array}{l}0.00 \\
\pm 0.00 \\
(0)\end{array}$ \\
\hline $\begin{array}{l}\text { Middle- } \\
\text { aged }\end{array}$ & 14 & $5 \pm 2$ & $\begin{array}{l}18.78 \\
\pm 22.34\end{array}$ & $\begin{array}{l}0.00 \\
\pm 2.16 \\
(6)\end{array}$ & $\begin{array}{l}0.00 \\
\pm 0.00 \\
(2)\end{array}$ & $\begin{array}{l}0.00 \\
\pm 1.87 \\
(6)\end{array}$ & $\begin{array}{l}0.95 \\
\pm 2.35 \\
(8)\end{array}$ & $\begin{array}{l}0.00 \\
\pm 1.20 \\
(5)\end{array}$ & $\begin{array}{l}3.83 \\
\pm 4.61 \\
(14)\end{array}$ & $\begin{array}{l}0.96 \\
\pm 0.99 \\
(8)\end{array}$ & $\begin{array}{l}10.45 \\
\pm 13.36 \\
(13)\end{array}$ & $\begin{array}{l}1.93 \\
\pm 4.38 \\
(10)\end{array}$ & $\begin{array}{l}0.48 \\
\pm 4.18 \\
(7)\end{array}$ & $\begin{array}{l}5.38 \\
\pm 10.03 \\
(11)\end{array}$ \\
\hline Old adults & 8 & $3 \pm 3$ & $\begin{array}{l}8.38 \\
\pm 9.74\end{array}$ & $\begin{array}{l}0.00 \\
\pm 0.74 \\
(2)\end{array}$ & $\begin{array}{l}0.00 \\
\pm 0.00 \\
(1)\end{array}$ & $\begin{array}{l}0.00 \\
\pm 0.74 \\
(2)\end{array}$ & $\begin{array}{l}0.00 \\
\pm 1.74 \\
(3)\end{array}$ & $\begin{array}{l}0.00 \\
\pm 0.73 \\
(2)\end{array}$ & $\begin{array}{l}4.94 \\
\pm 4.76 \\
(8)\end{array}$ & $\begin{array}{l}0.00 \\
\pm 0.00 \\
(0)\end{array}$ & $\begin{array}{l}3.98 \\
\pm 5.75 \\
(5)\end{array}$ & $\begin{array}{l}0.96 \\
\pm 3.44 \\
(4)\end{array}$ & $\begin{array}{l}0.00 \\
\pm 0.00 \\
(1)\end{array}$ & $\begin{array}{l}0.48 \\
\pm 4.58 \\
(4)\end{array}$ \\
\hline
\end{tabular}




\section{References}

Altmann, J. (1974). Observational study of behavior: sampling methods. Behaviour 49(3), 227-266. https://doi-org.passerelle.univrennes1.fr/10.1163/156853974X00534

Altmann, S. A. (1962). A field study of the sociobiology of rhesus monkeys, Macaca mulatta. Annals of the New York Academy of Sciences, 102(2), 338-435. https://doi.org/10.1111/j.1749$\underline{6632.1962 . t b 13650 . x}$

Altmann, S. A. (1967). The structure of primate social communication, Social communication among primates. In Social communication among primates (University of Chicago Press, p. 325-362).

Altmann, S. A. (1968). Primates. In: Animal communication - Techniques of study and results of research (Indiana University Press). Thomas A. Sebeok.

Anderson, J. R., Kuroshima, H., Hattori, Y., \& Fujita, K. (2010). Flexibility in the use of requesting gestures in squirrel monkeys (Saimiri sciureus). American Journal of Primatology 72(8), 707-714. https://doi.org/10.1002/ajp.20827

Arbib, M. A., Liebal, K., \& Pika, S. (2008). Primate Vocalization, Gesture, and the Evolution of Human Language. Current Anthropology 49(6), 1053-1076. https://doi.org/10.1086/593015

Aychet, J., Pezzino, P., Rossard, A., Bec, P., BloisHeulin, C., \& Lemasson, A. (2020). Red-capped mangabeys (Cercocebus torquatus) adapt their interspecific gestural communication to the recipient's behaviour. Manuscript submitted for publication.

Baraud, I. (2007). Interactions sociales et modalités sensorielles (vocale et visuelle) impliquées, chez deux espèces de mangabés (Cercocebus torquatus torquatus et Lophocebus albigena albigena) [Unpublished doctoral dissertation]. Université de Rennes 1

Baraud, I., Deputte, B. L., Pierre, J.-S., \& BloisHeulin, C. (2016). Informative Value of Vocalizations during Multimodal Interactions in Red-Capped Mangabeys. In Discovering Hidden Temporal Patterns in Behavior and Interaction ( $\mathrm{p}$. 255-277). Springer, New York, NY. https://doi.org/10.1007/978-1-4939-3249-8_14
Bard, K. A. (1992). Intentional Behavior and Intentional Communication in Young Free-Ranging Orangutans. Child Development, 63(5), 1186-1197. https://doi.org/10.1111/j.1467-8624.1992.tb01688.x

Bateson, G. (1955). A theory of play and fantasy. Psychiat. Res. Rept. A., 2, 39-51.

Benedek, M., \& Kaernbach, C. (2011). Physiological correlates and emotional specificity of human piloerection. Biological Psychology, 86(3), 320-329. https://doi.org/10.1016/j.biopsycho.2010.12.012

Bolwig, N. (1959). A study of the behaviour of the chacma baboon, Papio ursinus. Behaviour, 14, 136$163 . \quad$ https://doi-org.passerelle.univrennes 1.fr/10.1163/156853959X00054

Bouchet, H., Blois-Heulin, C., Pellier, A.-S., Zuberbühler, K, \& Lemasson, A. (2012). Acoustic variability and individual distinctiveness in the vocal repertoire of red-capped mangabeys (Cercocebus torquatus). Journal of Comparative Psychology, 126(1), 45-56. https://doi.org/10.1037/a0025018

Bouchet, H., Pellier, A.-S., Blois-Heulin, C., \& Lemasson, A. (2010). Sex differences in the vocal repertoire of adult red-capped mangabeys (Cercocebus torquatus): a multi-level acoustic analysis. American Journal of Primatology, 72, 360375. https://doi.org/10.1002/ajp.20791

Bourjade, M., Meguerditchian, A., Maille, A., Gaunet, F., \& Vauclair, J. (2013). Olive baboons, Papio anubis, adjust their visual and auditory intentional gestures to the visual attention of others. Animal Behaviour, 87, 121-128. https://doi.org/10.1016/j.anbehav.2013.10.019

Bretherton, I., \& Bates, E. (1979). The emergence of intentional communication. New Directions for Child and Adolescent Development, 1979, 81-100. https://doi.org/10.1002/cd.23219790407

Burrows, A. M. (2008). The facial expression musculature in primates and its evolutionary significance. BioEssays, 30(3), 212-225. https://doi.org/10.1002/bies.20719

Byrne, R. W., \& Bates, L. A. (2006). Why are animals cognitive? Current Biology, 16(12), R445448.

Byrne, R.W., Cartmill, E.A., Genty, E., Graham, K. E., Hobaiter, C., \& Tanner, J. E. (2017). Great ape 
gestures: intentional communication with a rich set of innate signals. Animal Cognition, 20, 755-769. https://doi.org/10.1007/s10071-017-1127-1

Call, J., Tomasello, M. (1994). Production and comprehension of referential pointing by orangutans. Journal of Comparative Psychology, 108(4), 307-317. https://doi.org/10.1037/07357036.108.4.307

Call, J., Tomasello, M. (Eds.). (2007). The gestural communication of apes and monkeys. Lawrence Erlbaum Associates, Publishers.

Canteloup, C., Bovet, D., \& Meunier, H. (2015a). Do Tonkean macaques (Macaca tonkeana) tailor their gestural and visual signals to fit the attentional states of a human partner? Animal Cognition, 18(2), 451461. https://doi.org/10.1007/s10071-014-0814-4

Canteloup, C., Bovet, D., \& Meunier, H. (2015b). Intentional gestural communication and discrimination of human attentional states in rhesus macaques (Macaca mulatta). Animal Cognition, 18(4), 875-883. https://doi.org/10.1007/s10071015-0856-2

Cartmill, E. A., \& Byrne, R. W. (2010). Semantics of primate gestures: intentional meanings of orangutan gestures. Animal Cognition, 13(6), 793804. https://doi.org/10.1007/s10071-010-0328-7

Cartmill, E. A., \& Byrne, R. W. (2007). Orangutans Modify Their Gestural Signaling According to Their Audience's Comprehension. Current Biology, 17(5), 1345-1348.

https://doi.org/10.1016/j.cub.2007.06.069

Cattaneo, L., \& Pavesi, G. (2014). The facial motor system. Neuroscience \& Biobehavioral Reviews, 38, 135-159.

https://doi.org/10.1016/j.neubiorev.2013.11.002

Chalmers, N. R. (1968a). The visual and vocal communication of free living mangabeys in Uganda. Folia Primatologica, 9, 258-280. https://doi.org/10.1159/000155183

Chalmers, N. R. (1968b). Group composition, ecology and daily activities of free living mangabeys in Uganda. Folia Primatologica, 8, 247-262. https://doi.org/10.1159/000155157

Chance, M. R. A., Emory, G. R., \& Payne, R. G. (1977). Status Referents in Long-tailed Macaques (Macaca fascicularis): Precursors and Effects of a
Female Rebellion. Primates, 18(3), 611-632. https://doi.org/10.1007/BF02383139

Chevalier-Skolnikoff, S. (1994). The primate playface: a possible key to determinants and evolution of play. Rice University Study, 60, 9-29.

Cooke, C. A. (2012). The feeding, ranging and positional behaviors of Cercocebus torquatus, the red-capped mangabey, in Sette Cama Gabon: a phylogenetic perspective. [Doctoral dissertation, Ohio State University].

De Marco, A., \& Visalberghi, E. (2007). Facial Displays in Young Tufted Capuchin Monkeys (Cebus apella):Appearance, Meaning, Context and Target. Folia Primatologica, 78(2), 118-137. https://doi.org/10.1159/000097061

de Waal, F. B. M., \& Luttrell, L. M. (1989). Toward a comparative socioecology of the genus Macaca: Different dominance styles in rhesus and stumptail monkeys. American Journal of Primatology, 19(2), 83-109, https://doi.org/10.1002/ajp.1350190203

Demuru, E., Ferrari, P. F., \& Palagi, E. (2015). Emotionality and intentionality in bonobo playful communication. Animal Cognition, 18(1), 333-344. https://doi.org/10.1007/s10071-014-0804-6

Dennett, D. C. (1983). Taking the intentional stance seriously. Behavioral and Brain Sciences, 6(3), 379390. https://doi.org/10.1017/S0140525X00016666

Deputte, B. (1978). Etude du bâillement chez deux espèces de Cercopithecidae, Cercocebus albigena albigena et Macaca fascicularis: Recherche des faceturs de causalité et de fonction. Mise en évidence de facteurs socio-bioénergétiques [Doctoral dissertation, Université de Rennes].

Deputte, B. (1986). Ontogénèse du cercocèbe à joues blanches en captivité (Lophocebus albigena) [Doctoral dissertation, Université de Rennes].

Deputte, B. (1992). Life history of captive graycheeked mangabeys: physical and sexual development. International Journal of Primatology, 13(5), 509-531. https://doi-org.passerelle.univrennes1.fr/10.1007/BF02547830

Deputte, B, (1994). Ethological Study of Yawning in Primates. I. Quantitative Analysis and Study of Causation in Two Species of Old World Monkeys (Cercocebus albigena and Macaca fascicularis). Ethology, 98, 221-245. https://doi- 
org.passerelle.univ-rennes1.fr/10.1111/j.14390310.1994.tb01073.x

Deshpande, A., Gupta, S., \& Sinha, A. (2018). Intentional communication between wild bonnet macaques and humans. Scientific Reports, 8(5147). https://doi.org/10.1038/s41598-018-22928-Z

Dettling, A., Pryce, C. R., Martin, R. D., \& Döbeli, M. (1998). Physiological responses to parental separation and a strange situation are related to parental care received in juvenile Goeldi's monkeys (Callimico goeldii). Developmental Psychobiology, 33(1), 21-31. https://doi.org/10.1002/(SICI)10982302(199807)33:1<21::AID-DEV3>3.0.CO;2-U

Diogo, R., Wood, B. A., Aziz, M. A., \& Burrows, A. (2009). On the origin, homologies and evolution of primate facial muscles, with a particular focus on hominoids and a suggested unifying nomenclature for the facial muscles of the Mammalia. Journal of Anatomy, 215(3), 300-319. https://doi.org/10.1111/j.1469-7580.2009.01111.x

Dobson, S. D. (2012). Coevolution of Facial Expression and Social Tolerance in Macaques: Facial Expression and Social Tolerance. American Journal of Primatology, 74(3), 229-235. https://doi.org/10.1002/ajp.21991

Dolado, R., \& Beltran, F.S. (2012). Emergent patterns of social organization in captive Cercocebus torquatus: Testing the GrooFiWorld agent-based model. Journal of Biosciences, 37(4), 777-784. https://doi.org/10.1007/s12038-012-9231-5

Dolado, Ruth, \& Beltran, F. S. (2011). Dominance hierarchy and spatial distribution in captive redcapped mangabeys (Cercocebus torquatus torquatus): Testing Hemelrijk's agent-based model. Interaction Studies, 12(3), 461-473. https://doi.org/10.1075/is.12.3.05dol

Dube, A. (2013). Visual and tactile communication of a captive hamadryas baboon group (Papio hamadryas hamadryas) with special regard to their intentionality [Doctoral dissertation, Universitätsund Landesbibliothek Sachsen-Anhalt].

Easley, S. P., \& Coelho, A. M. (1991). Is lipsmacking an indicator of social status in baboons? Folia Primatologica, 56, 190-201. https://doi.org/10.1159/000156547

Emery, N. J. (2000). The eyes have it: the neuroethology, function and evolution of social gaze. Neuroscience \& Biobehavioral Reviews, 24(6), 581-604. https://doi.org/10.1016/S01497634(00)00025-7

Freeberg, T. M., Dunbar, R. I. M., \& Ord, T. J. (2012). Social complexity as a proximate and ultimate factor in communicative complexity. Philosophical Transactions of the Royal Society B: Biological Sciences, 367(1597), 1785-1801. https://doi.org/10.1098/rstb.2011.0213

Friard, O., \& Gamba, M. (2016). BORIS: a free, versatile open-source event-logging software for video/audio coding and live observations. Methods in Ecology and Evolution, 7(11), 1325-1330. https://doi.org/10.1111/2041-210X.12584

Fröhlich, M., Sievers, C., Townsend, S. W., Gruber, T., \& van Schaik, C. P. (2019). Multimodal communication and language origins: integrating gestures and vocalizations. Biological Reviews, $0(0)$. https://doi.org/10.1111/brv.12535

Gautier-Hion, A., Colyn, M., \& Gautier, J.-P. (1999). Histoire naturelle des primates d'Afrique centrale. ECOFAC.

Gautier-Hion, A., \& Gautier, J.-P. (1976). Croissance, maturité sexuelle et sociale, reproduction chez les cercopithécinés forestiers africains. Folia Primatologica, 26, 165-184. https://doi.org/10.1159/000155749

Genty, E., Breuer, T., Hobaiter, C., \& Byrne, R. W. (2009). Gestural communication of the gorilla (Gorilla gorilla): repertoire, intentionality and possible origins. Animal Cognition, 12(3), 527-546. https://doi.org/10.1007/s10071-009-0213-4

Genty, E., Clay, Z., Hobaiter, C., \& Zuberbühler, K. (2014). Multi-Modal Use of a Socially Directed Call in Bonobos. PLOS ONE, 9(1), e84738. https://doi.org/10.1371/journal.pone.0084738

Graham, K. E., Furuichi, T., \& Byrne, R. W. (2017). The gestural repertoire of the wild bonobo (Pan paniscus): a mutually understood communication system. Animal Cognition, 20(2), 171-177. https://doi.org/10.1007/s10071-016-1035-9

Graham, K. E., Wilke, C., Lahiff, N. J., \& Slocombe, K. E. (2019). Scratching beneath the surface: intentionality in great ape signal production. Philosophical Transactions of the Royal Society B: Biological Sciences, 375(1789), 20180403. https://doi.org/10.1098/rstb.2018.0403 
Green, S. E. (1975). Variation of vocal pattern with social situation in the japanese monkey (Macaca fuscata): a field study. In Primate Behavior (p. 1-102). Elsevier Inc. https://doi.org/10.1016/B978$\underline{0-12-534004-5.50006-3}$

Gupta, S., \& Sinha, A. (2019). Gestural communication of wild bonnet macaques in the Bandipur National Park, Southern India. Behavioural Processes, 168, 103956. https://doi.org/10.1016/j.beproc.2019.103956

Hauser, M. D., Chomsky, N., \& Fitch, W. T. (2002). The Faculty of Language: What Is It, Who Has It, and How Did It Evolve? Science, 298(5598), 1569-1579.

https://doi.org/10.1126/science.298.5598.1569

Hauser, Marc D. (1996). The Evolution of Communication. MIT Press.

Hesler, N., \& Fischer, J. (2007). Gestural communication in Barbary macaques (Macaca sylvanus): an overview. In The Gestural Communication of Apes and Monkeys. Call, Josep and Tomasello, Michael.

Hill, W. C. O. (1974). Primates Comparative anatomy and taxonomy - Volume VII: Cynopithecinae (Cercocebus, Macaca, Cynopithecus) (Vol. 7). Edinburgh University press.

Hinde, R. A., \& Rowell, T. E. (1962). Communication by postures and facial expressions in the Rhesus monkey (Macaca mulatta). Proceedings of the Zoological Society of London, 138(1), 1-21. https://doi.org/10.1111/j.14697998.1962.tb05684.x

Hobaiter, C., \& Byrne, R. W. (2011a). The gestural repertoire of the wild chimpanzee. Animal Cognition, 14(5), 745-767. https://doi.org/10.1007/s10071-011-0409-2

Hobaiter, C., \& Byrne, R. W. (2011b). Serial gesturing by wild chimpanzees: its nature and function for communication. Animal Cognition, 14(6), 827-838. https://doi.org/10.1007/s10071-0110416-3

Hobaiter, C., \& Byrne, R. W. (2013). Flexibilité et intentionnalité dans la communication gestuelle chez les grands singes. Revue de primatologie, 5. https://doi.org/10.4000/primatologie.1713

Hopkins, W. D., Taglialatela, J., \& Leavens, D. A. (2011). Do chimpanzees have voluntary control of their facial expressions and vocalizations? In A. Vilain, J.-L. Schwartz, C. Abry, \& J. Vauclair (Eds.), Advances in Interaction Studies (Vol. 1, p. 71-88). John Benjamins Publishing Company. https://doi.org/10.1075/ais.1.05hop

Hostetter, A. B., Cantero, M., \& Hopkins, W. D. (2001). Differential use of vocal and gestural communication by chimpanzees (Pan troglodytes) in response to the attentional status of a human (Homo sapiens). Journal of Comparative Psychology, 115(4), 337-343. https://doi.org/10.1037//07357036.115.4.337

Jones, C., \& Sabater-Pi, J. (1968). Comparative ecology of Cercocebus albigena and Cercocebus torquatus in Rio Muni, West Africa. Folia Primatologica, 9, 99-113.

Leavens, D. A., \& Hopkins, W. D. (1998). Intentional communication by chimpanzees: a crosssectional study of the use of referential gestures. Dev Psychol., 34(5), 813-822. https://doi.org/10.1037//0012-1649.34.5.813

Leavens, D. A., Hopkins, W. D., \& Bard, K. A. (1996). Indexical and referential pointing in chimpanzees (Pan troglodytes). Journal of comparative psychology (Washington, D.C.: 1983), 110(4), 346-353. https://doi.org/10.1037/07357036.110.4.346

Leavens, D. A., Hopkins, W. D., \& Thomas, R. K. (2004a). Referential communication by chimpanzees (Pan troglodytes). Journal of Comparative Psychology, 118(1), 48. https://doi.org/10.1037/0735-7036.118.1.48

Leavens, D. A., Hostetter, A. B., Wesley, M. J., \& Hopkins, W. D. (2004b). Tactical use of unimodal and bimodal communication by chimpanzees, Pan troglodytes. Animal Behaviour, 67(3), 467-476. https://doi.org/10.1016/j.anbehav.2003.04.007

Leavens, D. A., Russell, J. L., \& Hopkins, W. D. (2005). Intentionality as measured in the persistence and elaboration of communication by chimpanzees (Pan troglodytes). Child development, 76(1), 291306. https://doi.org/10.1111/j.1467$\underline{8624.2005 .00845 . x}$

Leone, A., Ferrari, P. F., \& Palagi, E. (2014). Different yawns, different functions? Testing social hypotheses on spontaneous yawning in Theropithecus gelada. Scientific Reports, 4(1). https://doi.org/10.1038/srep04010 
Liebal, K., Call, J., \& Tomasello, M. (2004a). Use of gesture sequences in chimpanzees. American Journal of Primatology, 64(4), 377-396. https://doi.org/10.1002/ajp.20087

Liebal, K., Pika, S., Call, J., \& Tomasello, M. (2004b). To move or not to move: How apes adjust to the attentional state of others. Interaction Studies, 5(2), 199-219. https://doi.org/10.1075/is.5.2.03lie

Liebal, K., Pika, S., \& Tomasello, M. (2004c). Social communication in siamangs (Symphalangus syndactylus): use of gestures and facial expressions. Primates, 45(1),41-57. https://doi.org/10.1007/s10329-003-0063-7

Liebal, K., Pika, S., \& Tomasello, M. (2006). Gestural communication of orangutans (Pongo pygmaeus). Gesture, 6(1), 1-38. https://doi.org/10.1075/gest.6.1.02lie

Liebal, K., Waller, B. M., Burrows, A. M., \& Slocombe, K. E. (2014a). The morphology of primate communication. In Primate communication: a multimodal approach (p. 31-45). Cambridge University Press.

Liebal, K., Waller, B. M., Burrows, A. M., \& Slocombe, K. E. (2014b). Intentionality. In Primate communication: a multimodal approach (p. 169193). Cambridge University Press.

Liebal, K., Waller, B. M., Burrows, A. M., \& Slocombe, K. E. (2014c). Primate communication: a multimodal approach. Cambridge University Press.

Maestripieri, D. (1997). Gestural Communication in Macaques: Usage and Meaning of Nonvocal Signals. Evolution of Communication, 1(2), 193-222. https://doi.org/10.1075/eoc.1.2.03mae

Maestripieri, D. (2005). Gestural communication in three species of macaques (Macaca mulatta, $M$. nemestrina, $M$. arctoides): Use of signals in relation to dominance and social context. Gesture, 5(1-2), 57-73. https://doi.org/10.1075/gest.5.1.06mae

Maestripieri, D., \& Wallen, K. (1997). Affiliative and submissive communication in rhesus macaques. Primates, $38(2)$, 127-138. https://doi.org/10.1007/BF02382003

Maille, A., Engelhart, L., Bourjade, M., \& BloisHeulin, C. (2012). To Beg, or Not to Beg? That Is the Question: Mangabeys Modify Their Production of Requesting Gestures in Response to Human's
Attentional States. PLOS ONE, 7(7), e41197. https://doi.org/10.1371/journal.pone.0041197

Marler, P. (1967). Animal Communication Signals: We are beginning to understand how the structure of animal signals relates to the function they serve. Science, 157(3790), 769-774. https://doi.org/10.1126/science.157.3790.769

Marler, Peter. (1965). Communication in monkeys and apes. In I. DeVore (Ed.), Primate behavior Field studies of monkeys and apes (Holt, Rinehart and Winston, Inc.).

Meunier, H., Prieur, J., \& Vauclair, J. (2013). Olive baboons communicate intentionally by pointing. Animal Cognition, 16(2), 155-163. https://doi.org/10.1007/s10071-012-0558-y

Mitani, J. C., Call, J., Kappeler, P. M., Palombit, R. A., \& Silk, J. B. (Eds.). (2012). The evolution of primate societies. The University of Chicago Press.

Molesti, S., Meguerditchian, A., \& Bourjade, M. (2019). Gestural communication in olive baboons (Papio anubis): repertoire and intentionality. Animal Cognition. https://doi.org/10.1007/s10071-01901312-y

Müri, R. M. (2016). Cortical control of facial expression: Cortical Control of Facial Expression. Journal of Comparative Neurology, 524(8), 1578-1585. https://doi.org/10.1002/cne.23908

Noble, W. S. (2009). How does multiple testing correction work? Nature Biotechnology, 27(12), 1135-1137. https://doi.org/10.1038/nbt1209-1135

Orimaye, O. J. (2017). Density and Abundance of the Red-Capped Mangabey (Cercocebus Torquatus) In Omo Biosphere Reserve and Idanre Forest Reserve, South Western Nigeria. MOJ Proteomics \& Bioinformatics, $5(2)$. https://doi.org/10.15406/mojpb.2017.05.00156

Palagi, E. (2008). Sharing the motivation to play: the use of signals in adult bonobos. Animal Behaviour, 75(3), 887-896. https://doi.org/10.1016/j.anbehav.2007.07.016

Palagi, E., Leone, A., Mancini, G., \& Ferrari, P. F. (2009). Contagious yawning in gelada baboons as a possible expression of empathy. Proceedings of the National Academy of Sciences of the United States of America, 106(46), 19262-19267. https://doi.org/10.1073/pnas.0910891106 
Parr, L. A., Cohen, M., \& De Waal, F. B. M. (2005). Influence of Social Context on the Use of Blended and Graded Facial Displays in Chimpanzees. International Journal of Primatology, 26(1), 73-103. https://doi.org/10.1007/s10764-005-0724-z

Partan, S. R. (2002). Single and multichannel signal composition: facial expressions and vocalizations of rhesus macaques (Macaca mulatta). Behaviour, 139(8), 993-1027.

Phoenix, C. H., \& Chambers, K. C. (1982). Sexual behavior in adult gonadectomized female pseudohermaphrodite, female, and male rhesus macaques (Macaca mulatta) treated with estradiol benzoate and testosterone propionate. Journal of Comparative and Physiological Psychology, 96(5), 823-833. http://dx.doi.org/10.1037/h0077923

Pika, S., Liebal, K., \& Tomasello, M. (2003). Gestural communication in young gorillas (Gorilla gorilla): Gestural repertoire, learning, and use. American Journal of Primatology, 60(3), 95-111. https://doi.org/10.1002/ajp.10097

Pika, S., Liebal, K., \& Tomasello, M. (2005). Gestural communication in subadult bonobos (Pan paniscus): Repertoire and use. American Journal of Primatology, 65(1), 39-61. https://doi.org/10.1002/ajp.20096

Poggi, I., \& D’Errico, F. (2012). Social signals: a framework in terms of goals and beliefs. Cognitive Processing, 13(2), 427-445. https://doi.org/10.1007/s10339-012-0512-6

Pollick, A. S., \& De Waal, F. B. (2007). Ape gestures and language evolution, 104(19), 8184-8189. https://doi.org/10.1073/pnas.0702624104

Porter, S., ten Brinke, L., \& Wallace, B. (2012). Secrets and Lies: Involuntary Leakage in Deceptive Facial Expressions as a Function of Emotional Intensity. Journal of Nonverbal Behavior, 36(1), 23-37. https://doi.org/10.1007/s10919-011-0120-7

Poss, S. R., Kuhar, C., Stoinski, T. S., \& hopkins, W. (2006). Differential Use of Attentional and Visual Communicative Signaling by Orangutans (Pongo pygmaeus) and Gorillas (Gorilla gorilla) in Response to the Attentional Status of a Human. American journal of primatology, 68(10), 978-992. https://doi.org/10.1002/ajp.20304

Preuschoft, S., \& van Hooff, J. A. R. A. M. (1996). Homologizing primate facial displays: a critical review of methods. Folia Primatologica, 65(3), 121-137. https://doi.org/10.1159/000156878

R Core Team. (2018). R: A language and environment for statistical computing. R Foundation for Statistical Computing, Vienna, Austria. https://www.R-project.org/

Redican, W. K. (1975). Facial expressions in nonhuman primates. In L. A. Rosemblum (Éd.), Primate behavior: Developments in Field and Laboratory Research (p. 103-194). New York Academic Press. https://doi.org/10.1016/B978-0-12$\underline{\text { 534004-5.50007-5 }}$

Reynolds-Losin, E., Russell, J. L., Freeman, H., Meguerditchian, A., \& Hopkins, W. D. (2008). Left hemisphere specialization for oro-facial movements of learned vocal signals by captive chimpanzees. PLOS ONE, 3(6), e25 29. https://doi.org/10.1371/journal.pone.0002529

Roberts, A. I., Roberts, S. G. B., \& Vick, S.-J. (2014). The repertoire and intentionality of gestural communication in wild chimpanzees. Animal Cognition, 17(2), 317-336.

https://doi.org/10.1007/s10071-013-0664-5

Roberts, A. I., Vick, S.-J., \& Buchanan-Smith, H. M. (2013). Communicative intentions in wild chimpanzees: persistence and elaboration in gestural signalling. Animal Cognition, 16(2), 187-196. https://doi.org/10.1007/s10071-012-0563-1

Roberts, A. I., Vick, S.-J., Roberts, S. G. B., Buchanan-Smith, H. M., \& Zuberbühler, K. (2012). A structure-based repertoire of manual gestures in wild chimpanzees: statistical analyses of a graded communication system. Evolution and Human Behavior, 33(5), 578-589. https://doi.org/10.1016/j.evolhumbehav.2012.05.00 $\underline{6}$

Robinson, J. A., Scheffler, G., Eisele, S. G., \& Goy, R. W. (1975). Effects of Age and Season on Sexual Behavior and Plasma Testosterone and Dihydrotestosterone Concentrations of LaboratoryHoused Male Rhesus Monkeys (Macaca mulatta). Biology of Reproduction, 13(2), 203-210. https://doi.org/10.1095/biolreprod13.2.203

Roeder, J.-J., \& Gosset, D. (2001). La communication chez les primates non humains: de l'éthologie classique à l'éthologie cognitive. Primatologie, 4, 5-25 
Santana, S. E., Dobson, S. D., \& Diogo, R. (2014). Plain faces are more expressive: comparative study of facial colour, mobility and musculature in primates. Biology Letters, 10(5), 20140275. https://doi.org/10.1098/rsbl.2014.0275

Scheider, L., Waller, B. M., Oña, L., Burrows, A. M., \& Liebal, K. (2016). Social Use of Facial Expressions in Hylobatids. PLOS ONE, 11(3), e0151733.

https://doi.org/10.1371/journal.pone.0151733

Schel, A. M., Townsend, S.W., Machanda, Z., Zuberbühler, K., \& Slocombe, K. E. (2013) Chimpanzee Alarm Call Production Meets Key Criteria for Intentionality. PLOS ONE 8(10):e76674. https://doi.org/10.1371/journal.pone.0076674

Schel, A. M., Bono, A., Aychet, J., Pika, S., \& Lemasson, A. (under review). Intentionally produced body signals amongst red-capped mangabeys (Cercocebus torquatus). Manuscript submitted for publication.

Schino, G., \& Aureli, F. (1989). Do men yawn more than women? Ethology and Sociobiology, 10, $375-378$. https://doi.org/10.1016/01623095(89)90026-5

Sherwood, C. C., Hof, P. R., Holloway, R. L., Semendeferi, K., Gannon, P. J., Frahm, H. D., \& Zilles, K. (2005). Evolution of the brainstem orofacial motor system in primates: a comparative study of trigeminal, facial, and hypoglossal nuclei. Journal of Human Evolution, 48(1), 45-84. https://doi.org/10.1016/j.jhevol.2004.10.003

Sherwood, C. C., Holloway, R. L., Erwin, J. M., \& Hof, P. R. (2004). Cortical orofacial motor representation in Old World monkeys, great apes, and humans. Brain, behavior and evolution, 63(2), 82-106. https://doi.org/10.1159/000075672

Siegel, S., \& Castellan, N. J. (1988). Nonparametric statistics for the behavioral sciences (2nd ed). McGraw-Hill.

Sliwa, J., Takahashi, D. Y., \& Sheperd, S. (2018). Mécanismes neuronaux pour la communication chez les primates. Revue de primatologie, 9, 37. https://doi.org/10.4000/PRIMATOLOGIE.2950

Slocombe, K. E., Waller, B. M., \& Liebal, K. (2011). The language void: the need for multimodality in primate communication research. Animal Behaviour,
$81(5)$

919-924.

https://doi.org/10.1016/j.anbehav.2011.02.002

Tanner, J. E., \& Byrne, R. W. (1993). Concealing facial evidence of mood: Perspective-taking in a captive gorilla? Primates, 34(4), 451-457. https://doi.org/10.1007/BF02382654

Thierry, B. (2007). Unity in diversity: Lessons from macaque societies. Evolutionary Anthropology: Issues, News, and Reviews, 16(6), 224-238. https://doi.org/10.1002/evan.20147

Thierry, B., Bynum, E. L., Baker, S., Kinnaird, M. F., Matsumura, S., Muroyama, Y., O’Brien, T. G., Petit, O., \& Watanabe, K. (2000). The social repertoire of Sulawesi macaques. Primate Research, 16, 203-226.

Tomasello, M., Call, J., Nagell, K., Olguin, R., \& Carpentier, M. (1994). The learning and use of gestural signals by young chimpanzees: a transgenerational study. Primates, 35(2), 137-154. https://doi.org/10.1007/BF02382050

Tomasello, M., George, B. L., Kruger, A. C., Jeffrey, M., Farrar, \& Evans, A. (1985). The development of gestural communication in young chimpanzees. Journal of Human Evolution, 14(2), 175-186. https://doi.org/10.1016/S0047-2484(85)80005-1

Townsend, S. W., Koski, S. E., Byrne, R. W., Slocombe, K. E., Bickel, B., Boeckle, M., Braga Goncalves, I., Burkart, J. M., Flower, T., Gaunet, F., Glock, H. J., Gruber, T., Jansen, D. A. W. A. M., Liebal, K., Linke, A., Miklósi, Á., Moore, R., van Schaik, C. P., Stoll, S., ... Manser, M. B. (2017). Exorcising Grice's ghost: an empirical approach to studying intentional communication in animals. Biological Reviews of the Cambridge Philosophical Society, 92(3), 1427-1433. https://doi.org/10.1111/brv.12289

van Hooff, J. A. R. A. M. (1967). The Facial displays of the catarrhine monkeys and apes. In Primate Ethology (Weidenfeld and Nicolson, p. 7-68). Desmond Morris.

Vick, S.-J., \& Paukner, A. (2010). Variation and context of yawns in captive chimpanzees (Pan troglodytes). American Journal of Primatology, 72(3), 262-269. https://doi.org/10.1002/ajp.20781

Viera, A. J., \& Garrett, J. M. (2005). Understanding Interobserver Agreement: The Kappa Statistic. Family Medicine, 4. 
Visalberghi, E., Valenzano, D. R., \& Preuschoft, S. (2006). Facial Displays in Cebus apella. International Journal of Primatology, 27(6), 1689-1707. https://doi.org/10.1007/s10764-0069084-6

Wallen, K., \& Goy, R. W. (1977). Effects of estradiol benzoate, estrone, and propionates of testosterone or dihydrotestosterone on sexual and related behaviors of ovariectomized rhesus monkeys. Hormones and Behavior, 9(3), 228-248. https://doi.org/10.1016/0018-506X(77)90059-9

Waller, B. M., Caeiro, C. C., \& Davila-Ross, M. (2015). Orangutans modify facial displays depending on recipient attention. PeerJ, 3, e827. https://doi.org/10.7717/peerj.827

Waller, B. M., \& Cherry, L. (2012). Facilitating Play Through Communication: Significance of Teeth Exposure in the Gorilla Play Face: Facilitating Play Through Communication. American Journal of Primatology, 74(2), 157-164. https://doi.org/10.1002/ajp.21018

Waller, B. M., \& Micheletta, J. (2013). Facial Expression in Nonhuman Animals. Emotion Review, 5(1), 54-59. https://doi.org/10.1177/1754073912451503

Weigel, R. M. (1979). The Facial Expressions of the Brown Capuchin Monkey (Cebus apella). Behaviour, 68(3), 250-276.

Wolfheim, J. H., \& Rowell, T. E. (1972). Communication among captive talapoin monkeys (Miopithecus talapoin). Folia Primatologica, 18, 224-255. https://doi.org/10.1159/000155481

Zajonc, R. B. (1965). Social Facilitation. Science, 149(3681), 269-274.

https://doi.org/10.1126/science.149.3681.269

Zannella, A., Norscia, I., Stanyon, R., \& Palagi, E. (2015). Testing yawning hypotheses in wild populations of two strepsirrhine species: Propithecus verreauxi and Lemur catta: testing hypotheses on yawning in wild lemurs. American Journal of Primatology, 77(11), 1207-1215. https://doi.org/10.1002/ajp.22459

Zannella, A., Stanyon, R., \& Palagi, E. (2017). Yawning and social styles: Different functions in tolerant and despotic macaques (Macaca tonkeana and Macaca fuscata). Journal of Comparative
Psychology,

131(3),

179-188.

https://doi.org/10.1037/com0000062

Zumpe, D., Michael, R. P. (1986). Dominance index: A simple measure of relative dominance status in primates. American Journal of Primatology, 10, 291-300. https://doi.org/10.1002/ajp.1350100402 